\title{
Ocean Circulation and Tropical Variability in the Coupled Model ECHAM5/MPI-OM
}

\author{
J. H. Jungclaus, ${ }^{*}$ N. Keenlyside, ${ }^{+}$M. Botzet, ${ }^{*}$ H. HaAk, ${ }^{*}$ J.-J. Luo, ${ }^{\#}$ M. Latif, ${ }^{+}$J. Marotzke, ${ }^{*}$ \\ U. Mikolajewicz,* and E. RoecKneR* \\ * Max Planck Institute for Meteorology, Hamburg, Germany \\ + Leibniz-Institut für Meereswissenschaften, Kiel, Germany \\ \# Frontier Research System for Global Change, Yokohama, Japan
}

(Manuscript received 16 December 2004, in final form 2 September 2005)

\begin{abstract}
This paper describes the mean ocean circulation and the tropical variability simulated by the Max Planck Institute for Meteorology (MPI-M) coupled atmosphere-ocean general circulation model (AOGCM). Results are presented from a version of the coupled model that served as a prototype for the Intergovernmental Panel on Climate Change (IPCC) Fourth Assessment Report (AR4) simulations. The model does not require flux adjustment to maintain a stable climate. A control simulation with present-day greenhouse gases is analyzed, and the simulation of key oceanic features, such as sea surface temperatures (SSTs), large-scale circulation, meridional heat and freshwater transports, and sea ice are compared with observations.

A parameterization that accounts for the effect of ocean currents on surface wind stress is implemented in the model. The largest impact of this parameterization is in the tropical Pacific, where the mean state is significantly improved: the strength of the trade winds and the associated equatorial upwelling weaken, and there is a reduction of the model's equatorial cold SST bias by more than $1 \mathrm{~K}$. Equatorial SST variability also becomes more realistic. The strength of the variability is reduced by about $30 \%$ in the eastern equatorial Pacific and the extension of SST variability into the warm pool is significantly reduced. The dominant El Niño-Southern Oscillation (ENSO) period shifts from 3 to $4 \mathrm{yr}$. Without the parameterization an unrealistically strong westward propagation of SST anomalies is simulated. The reasons for the changes in variability are linked to changes in both the mean state and to a reduction in atmospheric sensitivity to SST changes and oceanic sensitivity to wind anomalies.
\end{abstract}

\section{Introduction}

The ongoing effort of the Intergovernmental Panel on Climate Change (IPCC; Houghton et al. 2001) reflects the history and development of the application of coupled atmosphere-ocean-sea ice general circulation models (AOGCMs) for climate prediction. The IPCC reports also document, however, the diversity of models and the dependence of the findings on the respective models and their parameterizations of subgrid-scale processes.

The Max Planck Institute for Meteorology (MPI-M) atmosphere (ECHAM) and ocean [MPI Ocean Model (MPI-OM)] models have undergone significant development in recent years. The technical details of these

Corresponding author address: Dr. Johann Jungclaus, Max Planck Institute for Meteorology, Bundesstrasse 53, 20146 Hamburg, Germany.

E-mail: johann.jungclaus@zmaw.de developments are described in Roeckner et al. (2003) for the atmosphere component and in Marsland et al. (2003) for the ocean model. Here we describe results from a version of the model that serves as a prototype for the IPCC fourth assessment report (AR4) simulations. A 300-yr present-day climate control simulation run is presented. The analysis concentrates on key climate variables such as sea surface temperature (SST), sea ice concentration and extents, oceanic heat and freshwater transports, and water mass transformations.

The accurate simulation of the equatorial SST climatology is crucial for a proper representation of the $\mathrm{El}$ Niño-Southern Oscillation (ENSO). A previous version of the model (Keenlyside et al. 2004) showed a pronounced cold bias in the equatorial Pacific, where the SST error in the western Pacific exceeded $4 \mathrm{~K}$. A number of attempts to improve the model by modifications to the physical parameterizations of friction and diffusion turned out to be largely unsuccessful. As has been found in the El Niño Simulation Intercomparison 
Project (ENSIP), the equatorial cold/warm bias is a problem common to many coupled models (Latif et al. 2001) and is related to the amplification of model errors by coupled feedbacks leading to an over-/underestimation of the divergence of equatorial ocean currents and associated upwelling. Although ENSO originates in the Tropics, it affects both the mean and the variability of global climate. Latif et al. (2000) showed that tropical feedbacks even influence the stability of the thermohaline circulation (THC). Reducing the easterly winds at the equator will certainly reduce the wind-driven ocean currents, their divergence, and the associated upwelling. While many studies have emphasized the sensitivity of stress to surface drag (e.g., Large and Pond 1981), there are only a few papers that deal with the impact of ocean currents on wind stress. Pacanowski (1987) suggested that wind stress be calculated from the velocity difference between the near-surface wind speed and the ocean current. He found significant changes in equatorial SST and in the seasonal cycle of the upwelling in a model experiment forced by climatological wind stress when the ocean currents were taken into account in the stress calculation. However, this approach did not find widespread application in coupled ocean-atmosphere models. We have implemented such a parameterization in our coupled model, following Luo et al. (2005).

The paper is structured as follows. The ocean model, the formulation of the parameterization of wind stress, and the experiments performed are described in section 2. In section 3, the model's climatology is compared with observations and in section 4, the simulation of tropical interannual variability is presented. The impacts of the new wind stress parameterization on the mean state and on interannual variability are described in the respective sections. A summary is presented in section 5 .

\section{The ocean and sea ice model}

The atmosphere model uses the cycle 5.2 of the ECHAM model family and is run at T63 resolution $\left(1.875^{\circ} \times 1.875^{\circ}\right)$ with 31 vertical (hybrid) levels. The ocean has $1.5^{\circ}$ average horizontal grid spacing with 40 unevenly spaced vertical levels. Technical details of the ocean model MPI-OM, the embedded sea ice model, and the parameterizations that have been implemented during the transition from the Hamburg Ocean Primitive Equation (HOPE) model (Wolff et al. 1997) to the MPI-OM model can be found in Marsland et al. (2003). Here we summarize the main features. The primitive equations for a hydrostatic Boussinesq fluid are formulated with a free surface. The vertical discretization is on $z$ levels, and the bottom topography is resolved by way of partial grid cells (Wolff et al. 1997). The spatial arrangement of scalar and vector variables is formulated on a C grid (Arakawa and Lamb 1977).

The along-isopycnal diffusion follows Redi (1982) and Griffies (1998). Isopycnal tracer mixing by unresolved eddies is parameterized following Gent et al. (1995). For the vertical eddy viscosity and diffusion the Richardson number-dependent scheme of Pacanowski and Philander (1981, hereafter PP) is applied. Since the PP scheme in its classical form underestimates the turbulent mixing close to the surface, an additional wind mixing is included that is proportional to the cube of the $10-\mathrm{m}$ wind speed and decays exponentially with depth.

In the presence of static instability, convective overturning is parameterized by greatly enhanced vertical diffusion. A slope convection scheme has been included that allows for a better representation of the flow of statically unstable dense water over sills, such as in Denmark Strait or in the Strait of Gibraltar (see Marsland et al. 2003 for details) and off shelves, such as on the Arctic and Antarctic shelves.

The dynamics of sea ice are formulated using viscous-plastic rheology (Hibler 1979). The thermodynamics relate changes in sea ice thickness to a balance of radiant, turbulent, and oceanic heat fluxes. The effect of snow accumulation on sea ice is included, along with snow-ice transformation when the snow/ice interface sinks below the sea level because of snow loading. The effect of ice formation and melting is accounted for within the model assuming a sea ice salinity of 5 psu.

An orthogonal curvilinear grid allows for an arbitrary placement of the grid poles. In the current setup, the model's North Pole is shifted to Greenland and the South Pole is moved toward the center of the Antarctic continent (Fig. 1). This approach not only removes the numerical singularity associated with the convergence of meridians at the geographical North Pole but also produces higher resolution in the deep water formation regions near Greenland (Greenland Sea and Labrador Sea) and in the Weddell Sea. In fact, the grid spacing is at minimum with about $15 \mathrm{~km}$ around Greenland and at maximum with $184 \mathrm{~km}$ in the Pacific. The topography was interpolated from the Earth Topography Five Minute Grid (ETOPO5; National Geophysical Data Center 1988) $1 / 12^{\circ}$ dataset, and specific topographic features, such as the important conduits of overflows and throughflows, were adjusted to observed sill depths.

Atmosphere and ocean are coupled by means of the Ocean-Atmosphere-Sea Ice-Soil (OASIS) coupler (Valcke et al. 2003). The ocean passes the SST, sea ice 


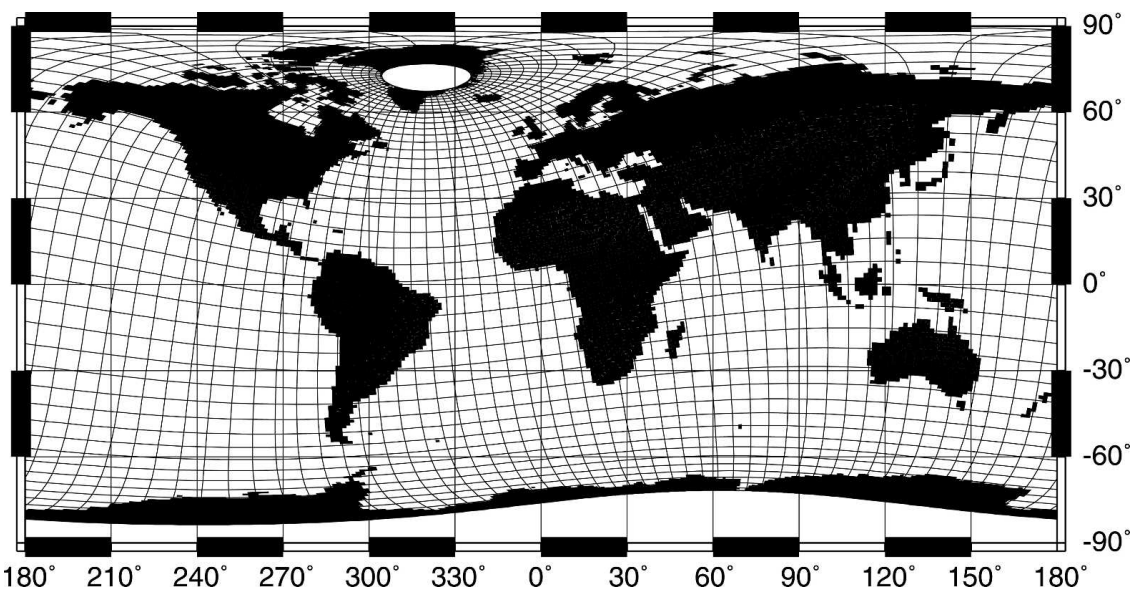

FIG. 1. Model grid (only every fifth grid line is displayed) and land-sea mask. White regions over Greenland and Antarctica denote the grid poles of the curvilinear grid.

concentration, sea ice thickness, snow depth, and the ocean surface velocities to the atmosphere. River runoff and glacier calving are treated interactively in the atmosphere model and the respective freshwater fluxes are passed to the ocean as part of the atmospheric freshwater flux field. The land hydrology model includes a river routing scheme (Hagemann and Dümenil 1998; Hagemann and Dümenil-Gates 2003), but the mass balance of glacier ice sheets is not accounted for in this model. Snowfall onto glaciers is, therefore, directly transferred to adjacent ocean points. None of the experiments described below require the use of flux adjustment.

\section{The effect of ocean currents on wind stress}

The surface wind speed is typically one or two orders of magnitude larger than the surface currents over much of the ocean. In equatorial regions, however, oceanic surface speeds can exceed $1 \mathrm{~m} \mathrm{~s}^{-1}$ (e.g., Weisberg 1984), while typical wind speeds are about 5-6 $\mathrm{m} \mathrm{s}^{-1}$ (Halpern 1988). For this reason, Pacanowski (1987) suggested that wind stress calculations should take into account the surface wind relative to the ocean flow:

$$
\tau=\rho C_{D}|\mathbf{W}-\mathbf{V}|(\mathbf{W}-\mathbf{V}),
$$

where $\rho$ and $C_{D}$ are the density of air and the drag coefficient, $\mathbf{W}$ is the lowest-level wind vector, and $\mathbf{V}$ is the ocean velocity vector, respectively. Pacanowski (1987) implemented (1) into an ocean model that was forced by climatological wind velocities and found the following effects: in the tropical Atlantic, the westward surface currents that are in the same direction as the wind stress were reduced by about $30 \%$, the North Equatorial Countercurrent was also reduced, and the equatorial upwelling decreased significantly. As a re- sult, there was an SST warming near the equator of about $1 \mathrm{~K}$, and cross-equatorial current profile simulation was in closer agreement with measurements.

Recently, Luo et al. (2005) have improved the equatorial cold bias in the Scale Interaction Experiment (SINTEX-F) coupled model by allowing for momentum transfer of the ocean currents to the atmosphere; we have adopted their "fully coupled" Wind Stress Correction (WSC) because this method reduced the cold bias much more than the "semi-coupled" version where the ocean currents enter only the bulk formulas for the wind stress calculation. The ocean velocities enter the wind stress calculations in two ways. First, the calculation of the vertical shear owing to friction is modified by using the ocean velocities as lower boundary conditions, rather than assuming a nonmoving surface. Second, the relative motion between the lowest atmospheric layer and the ocean surface is used in the calculation of the drag coefficient (and other turbulent mixing coefficients) assuming a law-of-the-wall formulation (Roeckner et al. 2003). Apart from the momentum fluxes, the $10-\mathrm{m}$ wind speed entering the calculation of the turbulent mixing in the upper layers of the ocean is modified accordingly. In the presence of sea ice, a similar modification is used for the air-ice stresses.

The SINTEX-F model described by Luo et al. (2005) has a relatively high resolution (T106 in the atmosphere) and, since it does not include a sea ice model, is mainly used to study low to midlatitude processes. Here, we apply the WSC to a state-of-the art climate model that is used for long-term integrations and climate change projections.

Two coupled experiments are performed in the present study. The standard run, on which the analysis 
a)

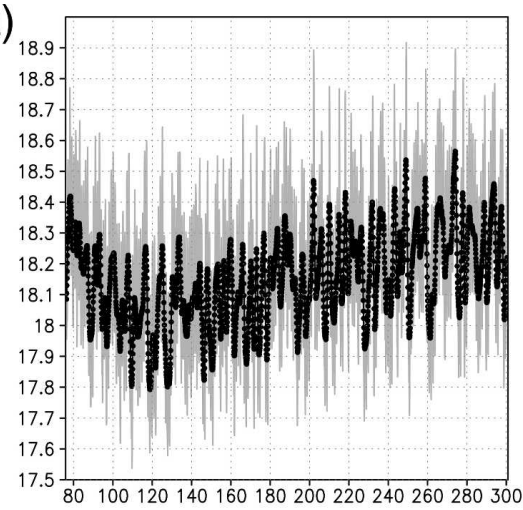

c)

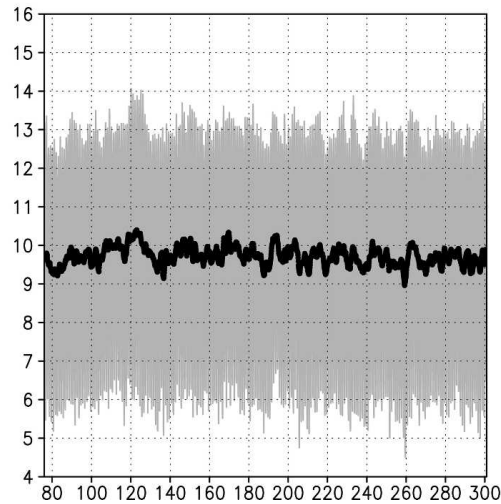

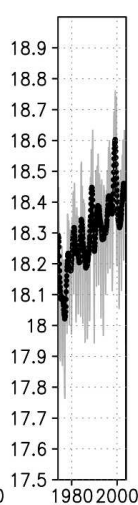

b)
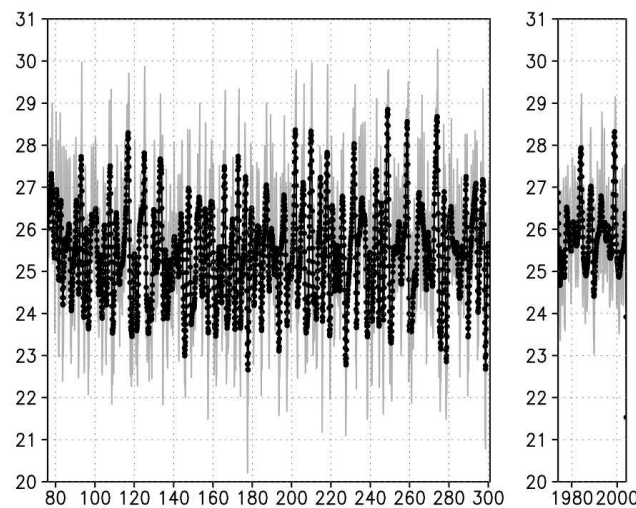

d)
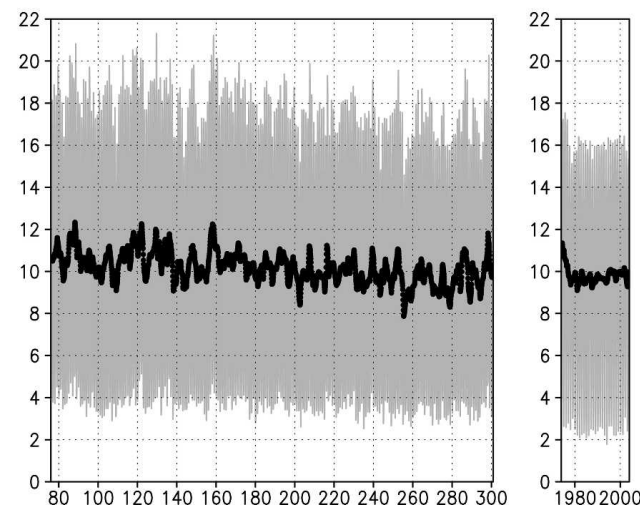

FIG. 2. Time series of (a) global mean SST $\left({ }^{\circ} \mathrm{C}\right)$, (b) SST $\left({ }^{\circ} \mathrm{C}\right)$ averaged over the Niño-3 region $\left(5^{\circ} \mathrm{S}-5^{\circ} \mathrm{N}\right.$, $\left.150^{\circ}-90^{\circ} \mathrm{W}\right)$, (c) Northern Hemisphere sea ice area $\left(10^{12} \mathrm{~m}^{2}\right)$, and (d) Southern Hemisphere sea ice area $\left(10^{12} \mathrm{~m}^{2}\right)$. The respective data from the HadISST climatology for the years 1980-2003 are shown for comparison to the right of each model time series. Thin lines denote monthly means; thick lines denote 12 -month running means.

of the mean state and the tropical variability is based, includes the parameterization for the effect of ocean surface currents on the wind speeds. This experiment is called WSC, whereas the respective run without this parameterization is named the No Wind Stress Correction (NWSC). Both experiments are run until the model year 300, but WSC is started from the output of year 77 of the NWSC experiment. NWSC, in turn, is started using the output of a climatologically forced ocean-only experiment. We analyze the results for the common period of model years 250-300. For comparison, SSTs and sea ice extents from the Hadley Centre Sea Ice and Sea Surface Temperature dataset (HadISST; Rayner et al. 2003) are used.

The time series of globally averaged SST (Fig. 2a) of experiment WSC shows an initial drop of $0.5 \mathrm{~K}$, recovery to roughly the initial value, consistent with the present-day HADISST climatology, and stabilization after about 200 yr. Between model years 250 and 300 the long-term temperature drift is less than $0.1 \mathrm{~K}$. The initial temperature decrease is caused by changes to the upper-ocean water mass properties following the intro- duction of the wind stress correction parameterization and subsequent changes in upwelling and vertical mixing (see below). The simulated SST in the Niño-3 region $\left(5^{\circ} \mathrm{S}-5^{\circ} \mathrm{N}, 150^{\circ}-90^{\circ} \mathrm{W}\right)$ is only slightly cooler than the observations from the last $20 \mathrm{yr}$ of the twentieth century. Neither the mean SST nor the envelope of the extremes shows significant trends over the last $100 \mathrm{yr}$ of the experiment. Although the simulation of tropical variability has been much improved compared to earlier versions of the MPI-M model and other AOGCMs (see van Oldenborgh et al. 2005) the simulation still overestimates the magnitude of the extremes. In particular, the cold (La Niña) events are approximately as strong and frequent as the warm El Niño events (see below). Northern Hemisphere sea ice extent (Fig. 2c) has a simulated annual mean of $9.7 \times 10^{12} \mathrm{~m}^{2}$, slightly lower than the annual mean from the HADISST data (Fig. 2d). Note, however, the drift in the observational data during the last two decades of the twentieth century that is most likely caused by multidecadal variability of the North Atlantic/Arctic climate system (Polyakov and Johnson 2000). While the monthly mean data 
indicate that the model simulates the summer extent well, the winter ice area is always smaller than the lowest winter estimate from the HADISST data. In the Southern Hemisphere, the model reproduces the observed annual mean of about $10 \times 10^{12} \mathrm{~m}^{2}$ and the summer ice extent well. Here, however, the winter maxima are about $10 \%$ higher than the climatological values. As will be shown below, there is too much ice spread northward into the Atlantic sector of the Southern Ocean. Generally, there is no significant trend in the ice area time series, indicating a well-balanced system.

Globally averaged subsurface temperature deviations from the Polar Science Center Hydrographic Climatology (PHC; Steele at al. 2001) climatology are relatively small at the beginning of the coupled experiment whereas initial salinity errors are larger, carried over from the climatologically forced ocean-only experiment (not shown). The distribution is consistent with the error patterns found in the uncoupled simulation of Marsland et al. (2003) and can be attributed to the inability of the model to maintain intermediate water mass properties in the Atlantic and the Pacific. There is a considerable drift in the temperature at intermediate and deep water levels that occurs during the coupled experiment. As a result, the model produces too warm and too salty deep water masses. This drift has, however, no pronounced effect on the THC.

\section{The mean state}

Sea surface temperature and sea ice are the most important ocean variables for the determination of the atmosphere-to-ocean fluxes and the realism of the coupling. Atmosphere-ocean freshwater fluxes are sensitive indicators of coupled model performance.

The difference between modeled surface temperature averaged over the last $50 \mathrm{yr}$ of the simulation WSC, and the Atmospheric Model Intercomparison Project (AMIP) surface temperature is shown in Fig. 3a. The deviation from the observed values is less than $1 \mathrm{~K}$ over much of the ocean. There are certain areas, however, where the discrepancy is considerably larger. The strongest bias is seen over the North Atlantic. The pathway of the North Atlantic Current (NAC) across the Atlantic is more zonally oriented than that observed, leading to a pronounced cold bias in the transition region between subtropical and subpolar gyres. On the other hand, the NAC transports too much heat (and salt; not shown) into the Nordic Seas and onto the Barents Shelf leading to too warm surface conditions there. Also, the Irminger and Labrador Seas in the northwestern Atlantic are too warm. Apparently, the
NAC loses too little heat to the atmosphere over the subpolar North Atlantic. Errors of similar magnitude, but opposite sign, occur in the Kuroshio region. A shift in the position of the Pacific boundary current system that is associated with large horizontal SST gradients leads to pronounced errors.

Positive SST biases occur at the western coasts of the Americas and Africa. This is a consequence of the lack of sufficient stratocumulus clouds in the atmosphere model, a feature that is widespread among state-of-theart coupled models (e.g., Barthelet et al. 1998; Gordon et al. 2000; Washington et al. 2000; Roberts et al. 2004). Finally, there are discrepancies in the Southern Ocean. In the Indian Ocean sector and the Australian sector, the SST is too high near Antarctica and too low on the northern flank of the Antarctic Circumpolar Current (ACC). The SST errors here are most likely caused by deficiencies in the simulation of the mixing of surface waters and the underlying Circumpolar Deep Waters (CDW) and errors in the position of the ACC. The SST in the central Pacific is off by slightly more than $1 \mathrm{~K}$ but matches the HadISST data well in the western Pacific. Compared to earlier model versions and other coupled models (Latif et al. 2001; Kiehl and Gent 2004), the cold bias in the equatorial Pacific is much improved. As discussed below, the new parameterization for wind stress is a major contributor to this improvement.

Precipitation is one of the most important climate variables, and the proper simulation of patterns and variability is still a challenge for coupled global climate models (Mechoso et al. 1995; Dai 2006). One outstanding feature is the so-called double intertropical convergence zone (ITCZ). In the Pacific, most models (without flux adjustment) simulate two perennial zonal bands of maximum precipitation straddling the equator, whereas in nature there is only a seasonal double ITCZ in the Pacific. The simulation presented here is no exception, as can be seen from the differences between the model precipitation and the Xie and Arkin (1997) observations (Fig. 3b). The northern ITCZ is shifted too much to the north and is too broad. There exists a dry bias directly at the equator, where SSTs are still too cold. South of the equator, there is a zonally oriented rainfall maximum that extends almost all the way to the South American coast. The southern ITCZ is accompanied by an overly dry region to the southwest of it. This pattern reflects the inability of the model to correctly simulate the precipitation pattern of the South Pacific convergence zone (SPCZ). Recently, Li et al. (2004) have analyzed several processes involved in the modeled double ITCZs. Their sensitivity studies show that two problems, still present in modern GCMs, lead to the erroneous structures: the overesti- 

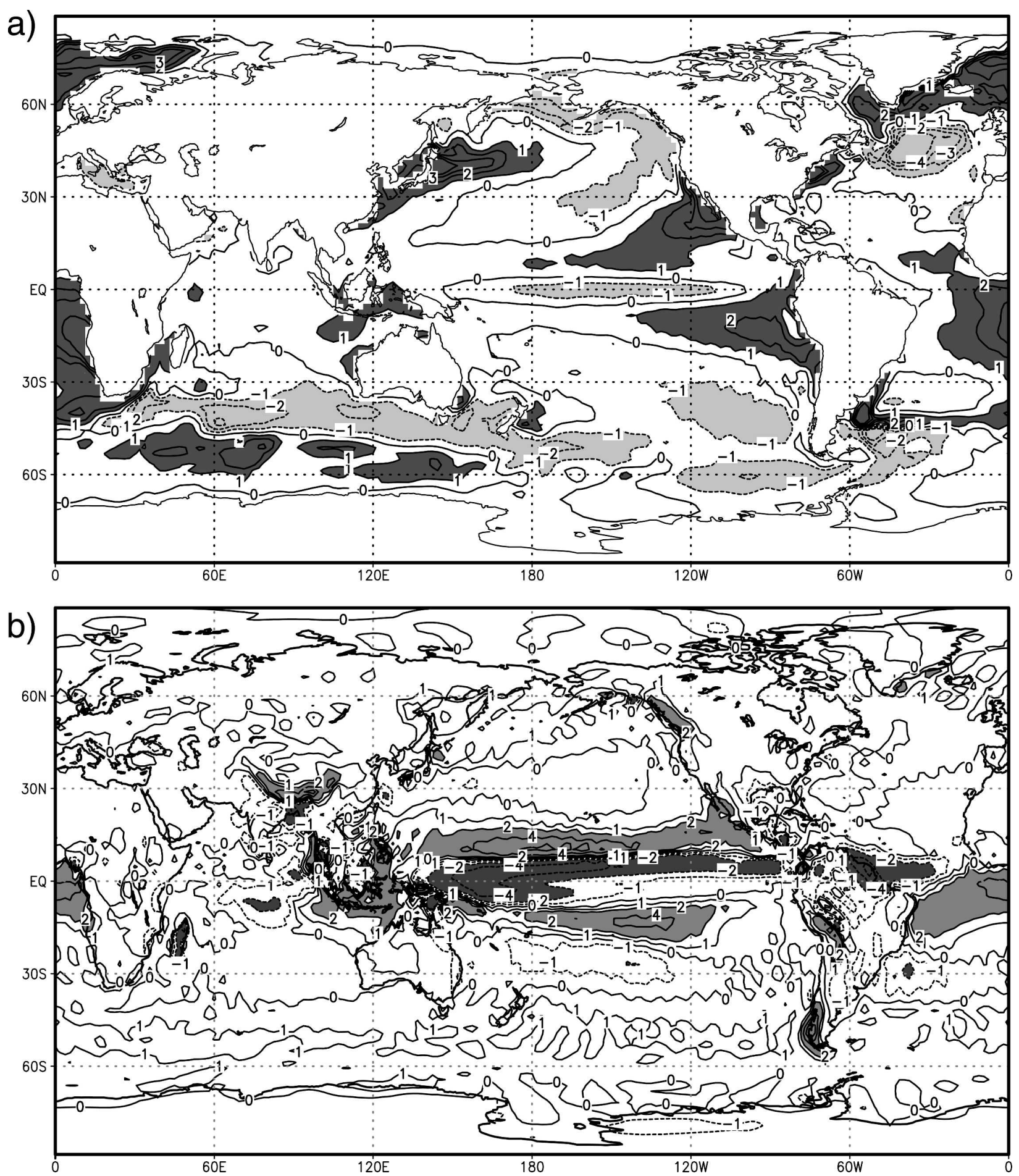

FIG. 3. (a) The model SST averaged over the last $50 \mathrm{yr}$ of the simulation (experiment WSC) minus the HadISST climatogical SST (K). Contour interval (CI) is $1 \mathrm{~K}$; regions where the SST error exceeds $1 \mathrm{~K}$ are shaded dark gray, and regions where the simulated SST is more than $1 \mathrm{~K}$ colder than the observations are shaded light gray; (b) the total precipitation field (mm day ${ }^{-1}$ ) of experiment WSC minus the mean annual precipitation from the Climate Prediction Center (CPC) Merged Analysis of Precipitation (CMAP; Xie and Arkin 1997). 
mated zonal wind stresses and erroneous equatorial zonal SST gradient on the one hand, and the warm bias of SSTs off the South American coast on the other hand. As will be shown below, the first process is affected positively by the application of the WSC. The second mechanism, which involves the underestimation of low-level stratus off the Peruvian coast and, possibly, ocean upwelling, is, however, a persistent problem also in our model (see also Dai 2006).

A realistic simulation of sea ice is crucial for a climate model because of the insulating effect of the ice cover and the ice-albedo feedback. Simulated sea ice concentrations are compared with monthly sea ice concentrations included in the HadISST dataset. The data for the Arctic are provided on a $1^{\circ}$ grid and cover the period 1870-2003. The modeled ice extent and its seasonal variation compares favorable with the satellite-based observations from the years 1978 to 2003 (Rayner et al. 2003). In the Northern Hemisphere (Figs. 4 a-d), the impact of the oceanic circulation on the ice coverage can be clearly seen. The warm Norwegian Atlantic current splits up into one branch that enters the Barents Shelf and the West Spitsbergen Current. As a result, the Barents Shelf and the western coast of Svalbard (territory of Norway) remain largely ice free in winter (Fig. 4b). Although the model underestimates the width of the ice-covered region to the east of Greenland, the southward extent of the ice edge just to Cape Farewell is well reproduced. The eastern part of the Labrador Sea remains ice free allowing for intensive air-sea exchange there. Both the simulation and the observations suggest that the winter ice concentration exceeds $90 \%$ for most of the ice-covered region. The model reproduces well the retreat of the sea ice boundary in summer. In September, the Barents and Kara Seas are largely ice free. The model underestimates, however, the summer melting on the Siberian and Canadian Shelves where the observations indicate ice concentrations less than $30 \%$ near the coasts. In contrast, simulated concentrations are lower than observed in the central Arctic. This reflects deficiencies in the simulation of the atmospheric wind field and the associated ice motion.

Simulated sea ice circulation in late winter and late summer (Figs. 4b,d) include well-known features, such as the Transpolar Drift Stream (TDS) and the anticyclonic gyre in the Canadian basin. A convenient feature of the placement of the grid poles over land is that there is no need for a special numerical treatment of the pole. Ocean models, which use a regular geographical grid often place an island directly onto the North Pole, artificially diverting the flow around the Pole. Compared to the satellite-derived Special Sensor Microwave Im- ager (SSM/I) data (Emery et al. 1997) and reconstructed circulation schemes (e.g., Colony and Thorndike 1984), our simulated anticyclonic Beaufort gyre, which is, in reality, confined to the Beaufort Sea, extends too far into the central Arctic. The TDS is therefore shifted too far to the European basin. This shift is even more pronounced in summer (Fig. 4d), where the center of anticyclonic motion spreads even more toward the North Pole. This simulated seasonal change does not agree with the buoy drift figures presented by Proshutinsky et al. (2002), who reported a weakening of the Beaufort gyre in summer but not a spatial shift. The ice transports largely reflect the overlying atmospheric circulation. In the simulation, the polar high is slightly too weak and located over the central Arctic in winter.

In the SSM/I data, the TDS is supplied primarily from Siberian coastal waters rather than from the Beaufort gyre. However, the model captures well the ice flow exiting from the Kara Sea that turns southward near Franz Josef Land and flows into the Barents Sea in winter. The model has two openings in the Canadian Archipelago, the passage from McClure Strait to Lancaster Sound, and the Nares Strait between Ellesmere Island and western Greenland. The major part of the Arctic ice exports toward the North Atlantic takes, however, the path through Fram Strait. The average Fram Strait ice export of $2618 \mathrm{~km}^{3} \mathrm{yr}^{-1}$ lies well in the range of observational estimates. Aagaard and Carmack (1989) calculated $2790 \mathrm{~km}^{3} \mathrm{yr}^{-1}$, Vinje (2001) reported $2900 \mathrm{~km}^{3} \mathrm{yr}^{-1}$, and Kwok et al. (2004) gave an estimate of $2218 \mathrm{~km}^{3} \mathrm{yr}^{-1}$.

The Southern Hemisphere ice concentrations (Figs. 4 e-h) are generally well simulated compared to the climatology, both in the seasonal variation and in the mean distribution. The model tends to underestimate the ice concentration in the Weddell Sea and the Ross Sea in winter. In particular, the austral winter concentration in the Weddell Sea gyre is reduced to values less than $50 \%$, indicating the occasional presence of open water (polynya). A further inspection of the HadISST sea ice data for the early 1970s (that did not enter Fig. $4 \mathrm{~g}$ ) confirms that such polynya situations indeed occur in reality. In the model, low ice concentrations occur in the center of the clockwise-rotating Weddell Sea gyre and indicate that relatively warm water is brought to the surface by convection (cf. Fig. 5). In the Atlantic sector, the sea ice extends too far to the north with a too strong clockwise-rotating Weddell Sea gyre that appears to be too strong. In austral summer, the simulation successfully reproduces the year-long presence of sea ice around the continent. The model slightly underestimates the ice extent off the Ross Sea and to the west 

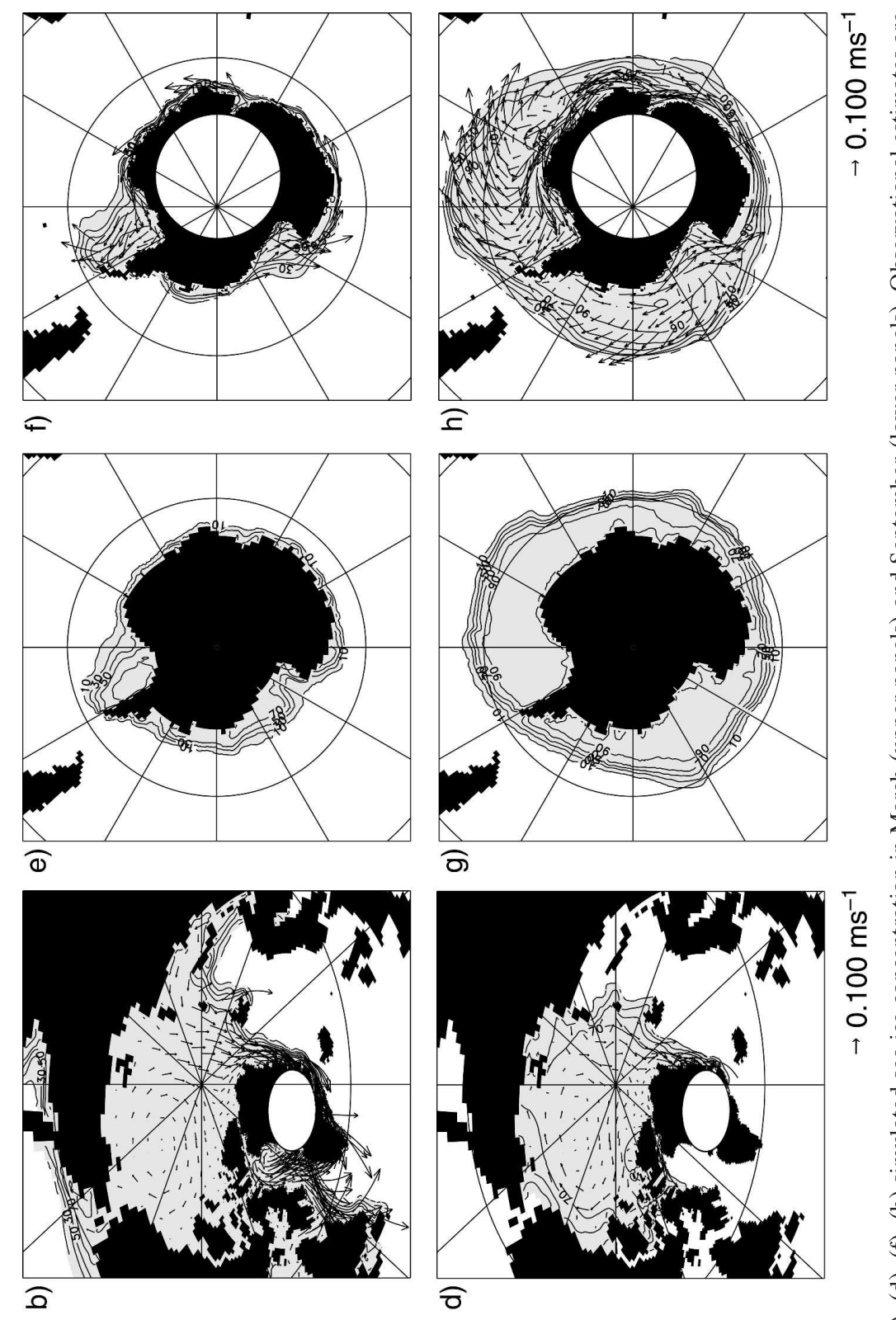

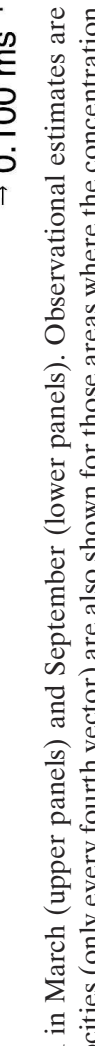
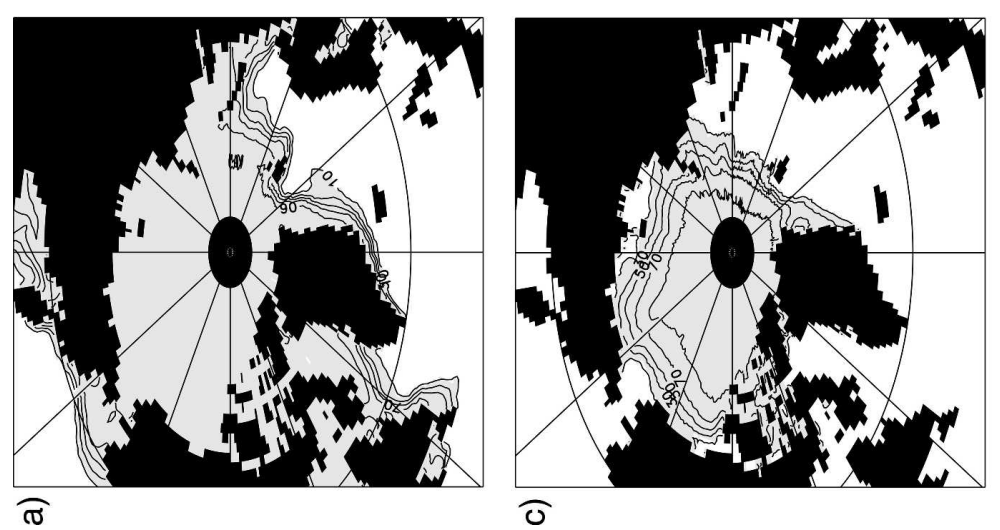

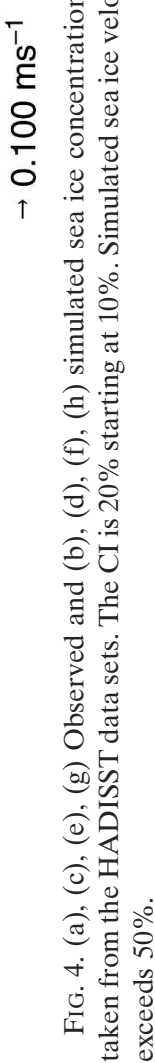


a)

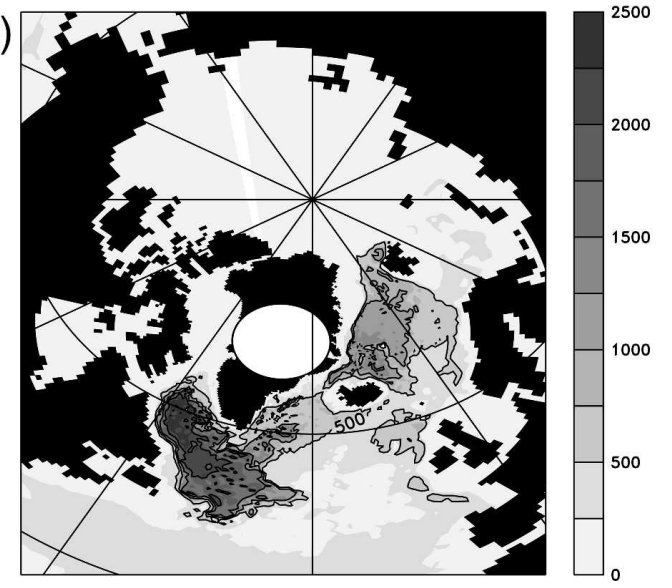

b)

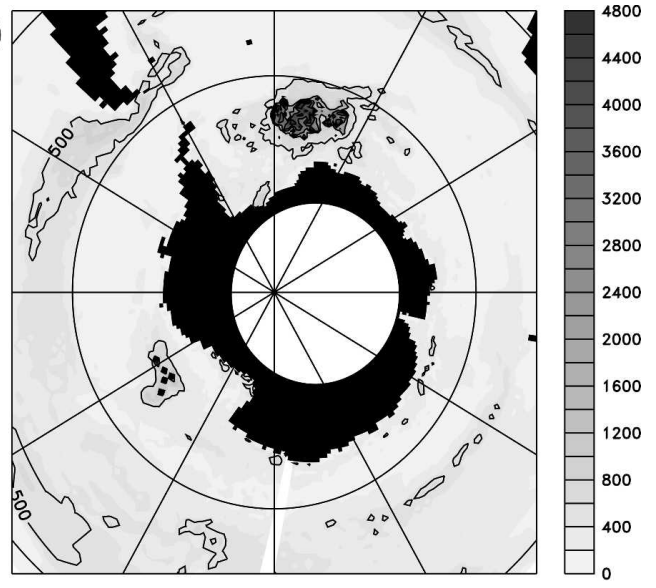

FIG. 5. Maximum depth $(\mathrm{m})$ of convective overturning $(\mathrm{m})$ during the years $250-300$. The CI is $500 \mathrm{~m}$.

of the Antarctic Peninsula. Also, in the Southern Hemisphere, the simulated ice motion captures the general patterns of Antarctic ice motion (e.g., Emery et al. 1997). The centers of the Weddell Sea and the Ross Sea gyres are placed approximately correctly when compared to the SSM/I data of Emery et al. (1997, their Fig. $2)$. There is a nearly continuous westward flow along the coast (the East Wind Drift) that, in some places (e.g., in the Ross Sea), bifurcates into clockwiserotating gyres.

Deep water formation in the Northern Hemisphere takes place both to the north and south of the Greenland-Scotland Ridge. Figure 5 shows the maximum depth of convection, diagnosed as the deepest model layer where the (diffusive) convection parameterization was active. In the Nordic Seas, convection exceeding $1000 \mathrm{~m}$ is widespread in the Greenland and Iceland Seas with maxima exceeding $1500 \mathrm{~m}$ in the Iceland Sea. The model fails to reproduce the convection in the central Greenland Sea gyre where too warm surface temperatures prevail (Fig. 3). The convective region to the south of Greenland extends from the Labrador Sea (LS) to the southeast, whereas it is much more confined to the LS in observations (e.g., Pickart et al. 2002). There is considerable temporal variation in the regional extent that is associated with changes in the subpolar gyre position variations of the atmospheric pressure field that are similar to the North Atlantic Oscillation (NAO). In the Southern Hemisphere, convection to abyssal depth occurs in the Weddell Sea but also at some grid points in the Ross Sea. A surface manifestation of the convection is the relatively low ice concentration in the central Weddell gyre in the 50-yr average shown in Fig. 4. Although open-ocean convection has been observed in the Weddell Sea (Gordon 1978), the observations are limited in time and space. In reality, most of the Antarctic Bottom Water (AABW) is formed on the shelves during polynya conditions (Orsi et al. 1999). As has been shown by Marsland et al. (2004), high resolution and an adequate representation of topographic details are required to realistically simulate high rates of sea ice growth and brine rejection. The evolution of the simulated water mass properties (too warm) and spreading rates of AABW indicate that the bottom water formation rate is too small in our model (not shown).

The time-averaged barotropic streamfunction reproduces the known general circulation features and gyre systems and is not reproduced here. Compared to observations, however, the path of the Gulf Stream extension (NAC) is too zonal. This is largely related to insufficient resolution that does not allow for a Gulf Stream separation at Cape Hatteras, North Carolina, and a proper representation of the pathway of the Deep Western Boundary Current (DWBC; C. Boening 2004, personal communication). As a result, the simulated circulation does not capture the northwest corner where the NAC in reality turns north, and the subpolar gyre extends too far to the east. The mass flux through Drake Passage of $165 \mathrm{~Sv}\left(1 \mathrm{~Sv} \equiv 10^{6} \mathrm{~m}^{3} \mathrm{~s}^{-1}\right)$ exceeds the estimates of $134 \pm 14$ Sv from Nowlin and Klinck (1986). The throughflow between Australia and Antarctica is about $170 \mathrm{~Sv}$ compared to $147 \pm 10 \mathrm{~Sv}$ estimated from repeated sections by Rintoul and Sokolov (2001). The strength of the ACC depends on the resolution of topographic details, such as the South Sandwich Islands, and on the choice of isopycnal diffusivity (Gent et al. 1998, 2001). Other large-scale oceanic volume transports are as follows: Florida Strait transport is about $24 \mathrm{~Sv}$, compared to an estimate of about $32 \mathrm{~Sv}$ by Larsen (1992); the Indonesian throughflow is $13 \mathrm{~Sv}$, whereas Wijffels et al. (1996) give an estimate of $7 \pm 12$ 
Sv. The relatively dense waters flow $\left(\sigma_{\theta}>27.8\right)$ through the Denmark Strait and the Faeroe Bank Channel form the core of the lower North Atlantic Deep Waters (NADW). In the model, overflow transport rates at the sills are close to 2.5 and $2 \mathrm{~Sv}$, respectively, in agreement with observations (Ross 1984; Saunders 1990). As was demonstrated by Marsland et al. (2003) the newly implemented bottom boundary layer scheme improves the water mass properties as the overflows descend the steep slopes of the sill and mix with ambient waters.

The large-scale ocean transports can further be visualized by the meridional streamfunction calculated from the mean velocities. The zonally integrated Atlantic streamfunction in latitude-depth space shows the tropical-subtropical overturning cells with their usual asymmetry about the equator (Fig. 6). The conveyor belt circulation is represented by the clockwise-rotating cell associated with the formation of NADW in the North Atlantic and the counterclockwise rotating AABW cell. In the Atlantic, the NADW cell reaches a maximum of $18.5 \mathrm{~Sv}$ at about $40^{\circ} \mathrm{N}$ at a depth of $1000 \mathrm{~m}$. This compares well with the observational estimates of $18 \pm 4 \mathrm{~Sv}$ (Macdonald 1998) and $18 \mathrm{~Sv}$ (Talley et al. 2003). More than $15 \mathrm{~Sv}$ are exported at $30^{\circ} \mathrm{S}$. The AABW cell in the Atlantic has a maximum of about 3.3 Sv, and about $3 \mathrm{~Sv}$ enter the South Atlantic at $30^{\circ} \mathrm{N}$. Compared to estimates from inverse models, the AABW rates are rather low. Sloyan and Rintoul (2001) and Ganachaud and Wunsch (2000) suggested an AABW inflow of about $6 \mathrm{~Sv}$. Moreover, the AABW cell weakens considerably over the course of the experiment from more than $5 \mathrm{~Sv}$ to $3.3 \mathrm{~Sv}$. Apparently, the formation of AABW with correct water mass properties is insufficient in this model owing to insufficient bottom water formation on the Antarctic shelves. On the other hand, the strength and structure of the NADW cell is quite stable.

The simulated global heat transports compare favorably with the estimates from direct observations and inverse calculations (Figs. 7 a,c). The maximum poleward heat transports are $1.8 \mathrm{PW}$ near $26^{\circ} \mathrm{N}$ in the Northern Hemisphere and $-1.7 \mathrm{PW}$ near $10^{\circ} \mathrm{S}$ in the Southern Hemisphere. In the Atlantic, the simulated transports are within the range of uncertainty of the Trenberth and Solomon (1994) estimates but fail to reproduce the numbers obtained from inverse calculations [e.g., Ganachaud and Wunsch's (2003) estimate of $1.27 \pm 0.15 \mathrm{PW}$ at $\left.24^{\circ} \mathrm{N}\right]$. The global heat flux imbalance of nearly 0.4 PW $(\sim 1 \mathrm{~W}$ per square meter of ocean surface) reflects the heat uptake by the deep ocean that has not yet equilibrated. This number is of the same order as the estimated upper-ocean $(0-750 \mathrm{~m})$ warming

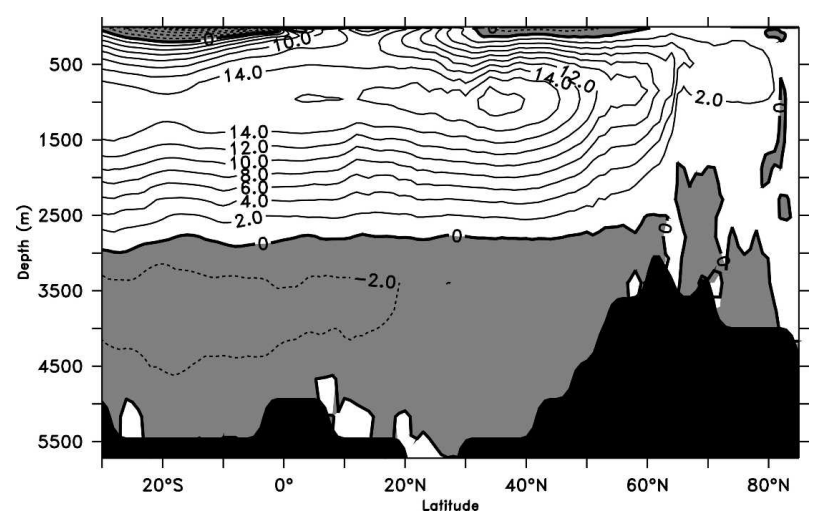

FIG. 6. Mean Atlantic meridional overturning streamfunction averaged over the years $250-300$. The CI is $2 \mathrm{~Sv}$; negative values are shaded.

estimated from the 1993-2003 observations by Willis et al. (2004).

Observational estimates of freshwater fluxes usually have large uncertainties, and indirect calculations from observation-based climatologies (e.g., Josey et al. 1996; Da Silva et al. 1994) show considerable differences (Wijffels 2001). The simulated global meridional freshwater transport (Fig. 7b), as implied by the long-term average of the atmosphere to ocean freshwater flux, reproduces the general features of the estimates from inverse calculations, such as the latitudes of sign changes. However, the simulated maximum of $1.25 \mathrm{~Sv}$ around $40^{\circ} \mathrm{S}$ exceeds the direct and indirect estimates discussed in Wijffels (2001). In the Atlantic (Fig. 7d), the most robust discrepancy between the observational estimates and the simulation is the much too negative freshwater flux poleward of $30^{\circ} \mathrm{N}$.

\section{The effect of the surface stress formulation on the mean state}

We now quantify the impact of the new wind stress parameterization on the mean state (defined here as the 250-300-yr average) by comparing the experiment WSC with an otherwise identical simulation without the wind shear correction (NWSC). The impact of the parameterization can be thought of as arising from two effects. The first, and most straightforward to understand, is simply due to the change in the magnitude (and curl) of the wind stress seen by the ocean. The second, which is nontrivial to diagnose, is due to changes in the feedbacks between the ocean and the atmosphere, for example, due to changes in atmospheric and oceanic sensitivity that result either from the direct effect of the atmosphere being influenced by the ocean currents, or from changes in the mean state 

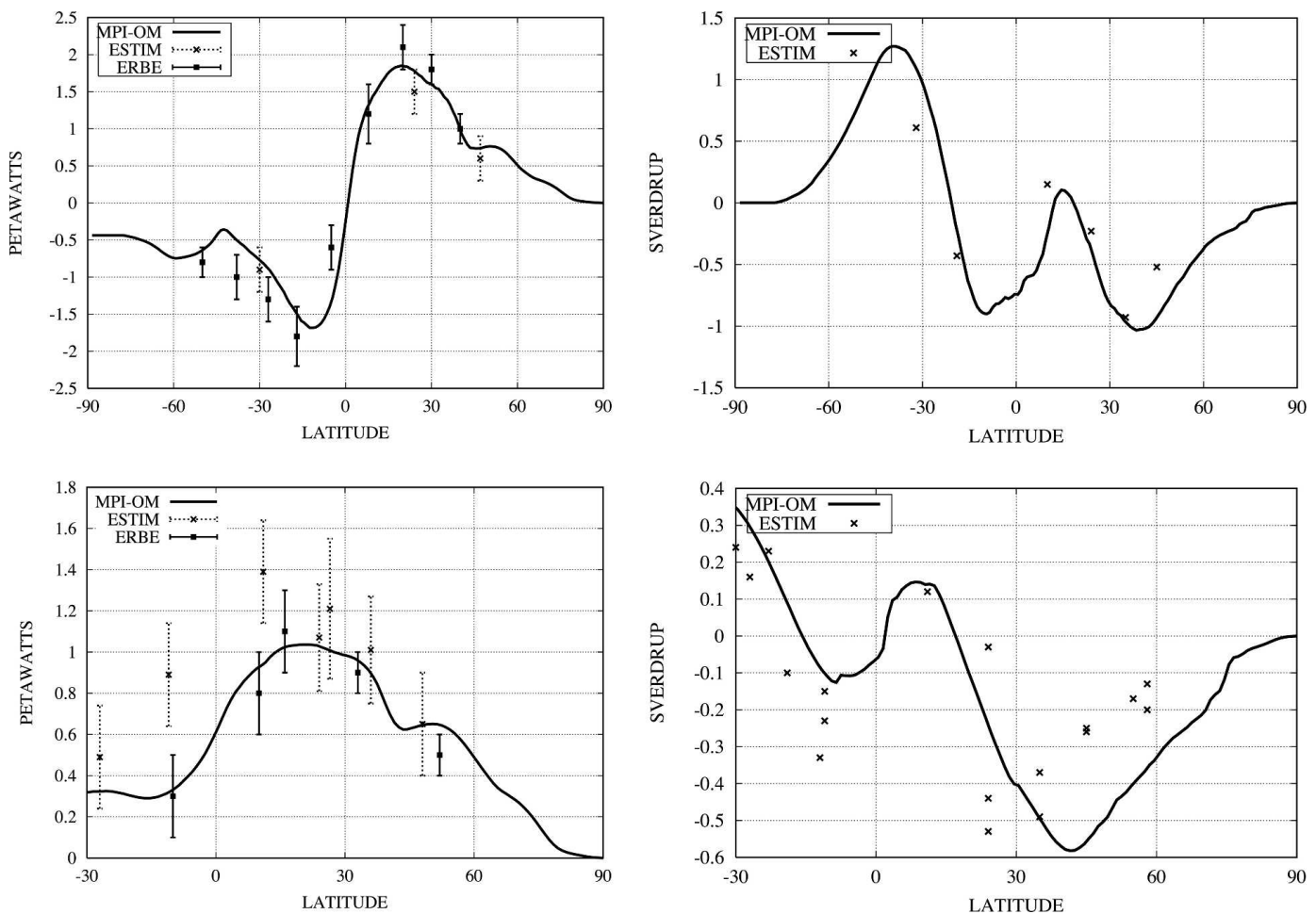

FIG. 7. Meridional (top) global and (bottom) Atlantic (left) heat and (right) freshwater transports implied by ocean-to-atmosphere fluxes. The ocean data were averaged over the last $50 \mathrm{yr}$ of the simulation. Heat transport estimates with error bars based on observations are taken from Rintoul and Wunsch (1991), Macdonald and Wunsch (1996), and Johns et al. (1997). Estimates derived from the top of the atmosphere as part of the Earth Radiation Budget Experiment (ERBE) are taken from Trenberth and Solomon (1994). Freshwater transport based on direct observations are taken from various sources compiled in Wijffels (2001).

itself. As expected, the parameterization affects the wind stress curl (Fig. 8a) mostly where ocean speeds are high. In the Southern Ocean, winds and the upper layer of the ocean move in the same direction so that there is both a reduction of (the usually positive) wind stress curl on the northern flank of the ACC and a reduction of negative stress curl to the south of the ACC axis. There is also a clear effect in the regions of the boundary currents on the eastern coasts of the continents, such as the North Brazil Current and the Gulf StreamNorth Atlantic Current. There are only minor changes in the wind stress curl over the equatorial Atlantic, while the changes in the Pacific equatorial currentwind system leave a clear imprint on the wind stress curl distribution. The changes are mainly due to a reduction of the westward component of the wind stress. The reduction of the wind stress anomalies in the ACC region is associated with a reduction of easterly wind stress anomalies in the Tropics by means of the global angular momentum balance. The gain of angular momentum in the Tropics must be balanced by loss in the extratropics. The sensitivity experiments in Luo et al.
(2005) show that the influence of the atmospheric general circulation adjustment contributes significantly to the reduction of the easterly trade winds.

Large positive differences in the western and central equatorial Pacific SSTs are apparent (Fig. 8b), where the cold bias is reduced by more than $1 \mathrm{~K}$. As a result, SST deviations from the HadISST climatology (Fig. 3a) are relatively small in the warm pool. Comparing Fig. $8 \mathrm{~b}$ and Fig. 3a further indicates that the SST errors in the Barents Sea, near Bering Strait, and in the Weddell and Ross Seas would be larger without the new parameterization. In contrast, there is only slight improvement in the warm-bias zones off the western coasts of South America and off South Africa. Moreover, near the Peruvian coast, the modified wind stresses do not favor enhanced upwelling so that the lower SSTs must be due to changes in frontal positions and/or changed atmospheric conditions [in contrast to Luo et al.'s (2005) findings]. Although Fig. 8a showed considerable changes in the wind stress curl over the boundary region of the subtropical and subpolar gyres in the North Atlantic, there is no improvement in the too cold North 
Atlantic where the SST errors are more likely due to shortcomings in the ocean resolution.

A comparison of the precipitation changes between WSC and NWSC reveals most pronounced differences in the equatorial regions of the Pacific and Indian Oceans. In the western Pacific, the dry bias is reduced by up to $2.5 \mathrm{~mm}$ day $^{-1}$ (roughly $30 \%$ ), but not eliminated (cf. Fig. 3b). This supports the finding of $\mathrm{Li}$ et al. (2004), who stated that the equatorial component of the double ITCZ phenomenon is related to overestimation of the easterly winds in the central equatorial Pacific. There is also a slight reduction in the wet bias to the south of the equator in the central Pacific. Here, where we only see a slight improvement of the overly warm SSTs (cf. Fig. 3a); the model still produces a southern ITCZ and fails to reproduce the typical northwestsoutheast orientation of the rainfall maximum associated with the SPCZ. Li et al. (2004) have pointed out that the southern ITCZ in the models is mainly related to the warm bias in the surface waters that originate from the lack in stratocumulus clouds off the coast of South America.

In the equatorial Pacific, the new wind stress parameterization leads to a pronounced reduction in zonal wind stress (Fig. 9). At the equator, the wind stress reduction is largest in the western and central Pacific. The resulting convergence (Fig. 9b) leads to more pronounced convective precipitation over the warmer western Pacific (Fig. 8c). There is an intensification of the winds blowing toward the equator to the east of Australia caused by the warmer SST in the western Pacific. Weaker equatorial surface stresses are to be expected, since, at the equator, the ocean currents and surface trade winds are both westward. The trade winds drive the westward surface current and the South Equatorial Current (SEC) and also induce poleward Ekman transports and equatorial upwelling. Reduced wind stresses thus produce a weaker equatorial circulation and divergence. In the western Pacific, ocean surface speeds are reduced by more than $0.4 \mathrm{~m} \mathrm{~s}^{-1}$ (not shown). Equatorial upwelling is reduced across the basin, with the largest changes in the western Pacific and near Indonesia (Fig. 9c). In the central Pacific, the mean equatorial upwelling at $50 \mathrm{~m}$ is around $2 \times 10^{-5} \mathrm{~m} \mathrm{~s}^{-1}(\sim 630$ $\mathrm{m} \mathrm{yr}^{-1}$ ), which corresponds to a $30 \%$ reduction as compared to the NWSC run and is well within the range of observational estimates (e.g., Weisberg and Qiao 2000) and is consistent with other models (e.g., Large et al. 2001).

These changes modify the time-mean equatorial mixed layer heat budget. The temperature tendency from various contributions is stored in the model, and time averages, integrated over the upper $50 \mathrm{~m}$ [used as a)

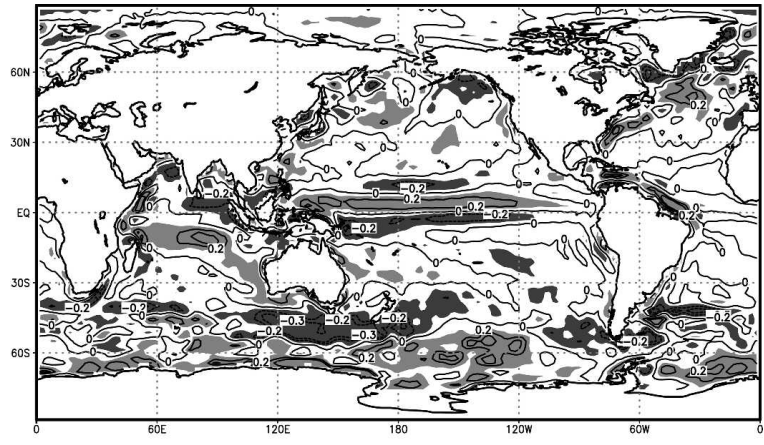

b)

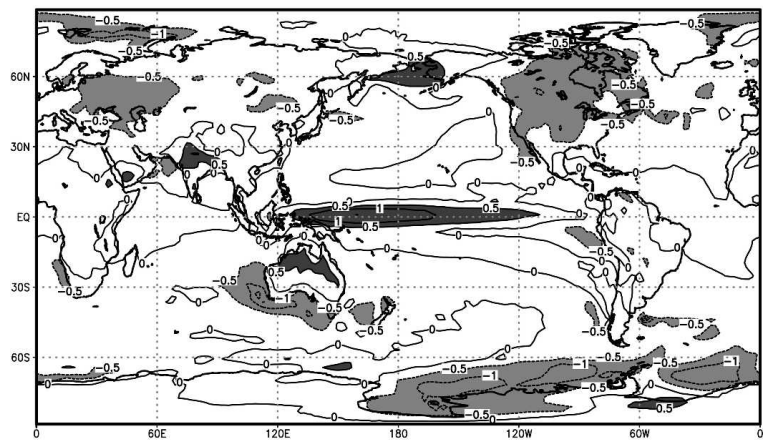

c)

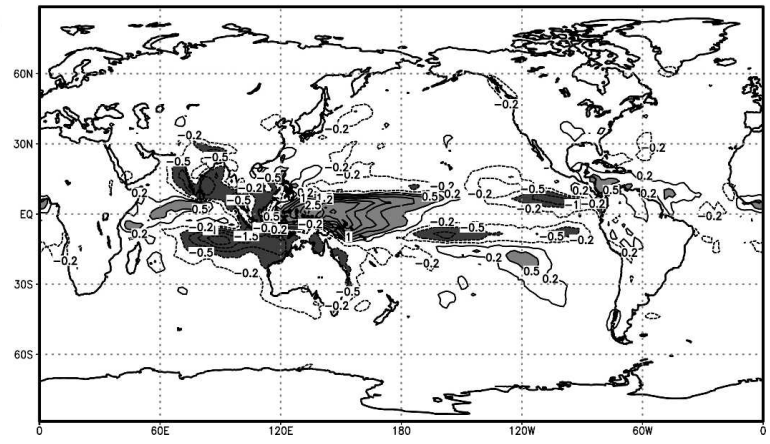

FIG. 8. Change in (a) wind stress curl $\left(10^{-7} \mathrm{Nm}^{-3}\right)$, (b) surface temperature $(\mathrm{K})$, and (c) precipitation $\left(\mathrm{mm} \mathrm{day}^{-1}\right)$ between the experiment including the WSC and the respective experiment without this parameterization (NWSC). For both experiments the fields were averaged over the model years $250-300$. In (a), the CI are $-0.3,-0.2,0,0.2$, and $0.3 \times 10^{-7} \mathrm{Nm}^{-3}$; values exceeding 0.1 $10^{-7} \mathrm{Nm}^{-3}$ are shaded light gray, and values less than $-0.1 \mathrm{Nm}^{-3}$ are shaded dark gray. In (b) the $\mathrm{CI}$ is $0.5 \mathrm{~K}$; values exceeding 0.5 $\mathrm{K}$ are shaded dark gray, and values less than $-0.5 \mathrm{~K}$ are shaded light gray. In (c) the CI is $0.5 \mathrm{~mm} \mathrm{day}^{-1}$, but the -0.2 and $0.2 \mathrm{~mm}$ day $^{-1}$ isolines are displayed instead of the (noisy) zero contours.

an estimate of the mean mixed layer depth (Huang and Liu 2002; Vialard et al. 2001)], are displayed in Fig. 10. The total temperature tendency is small in the longterm mean. In the eastern equatorial Pacific, the mixed layer temperature is maintained by warming by surface heat fluxes and meridional advection and cooling by vertical advection (upwelling) through the mixed layer base. In the western Pacific, the balance is made up by surface warming and cooling by zonal advection and 
a)

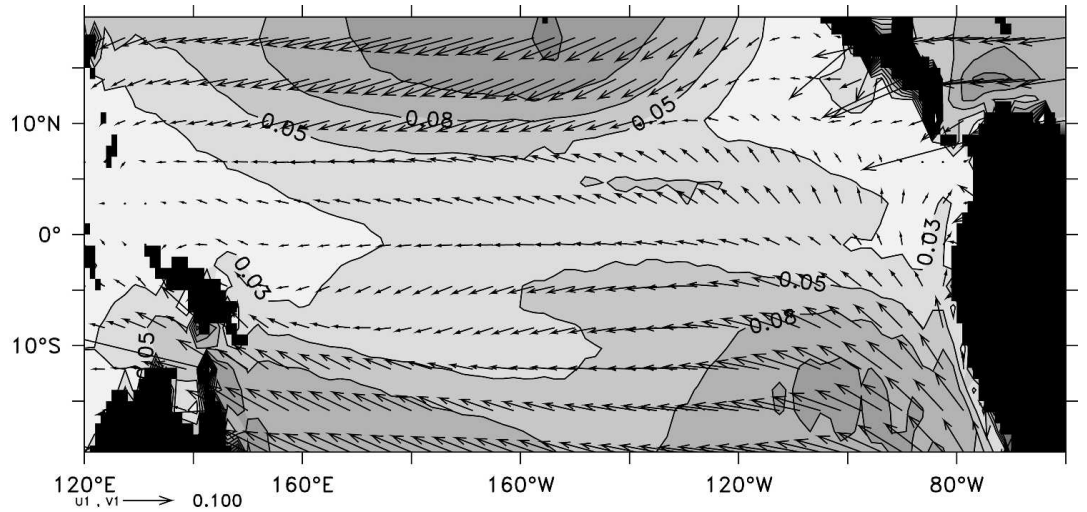

b)

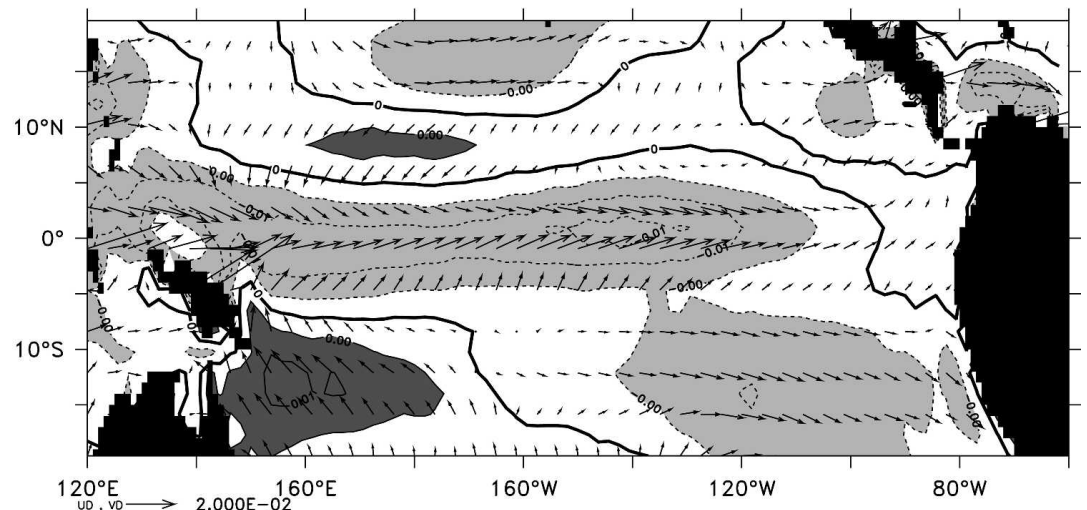

c)

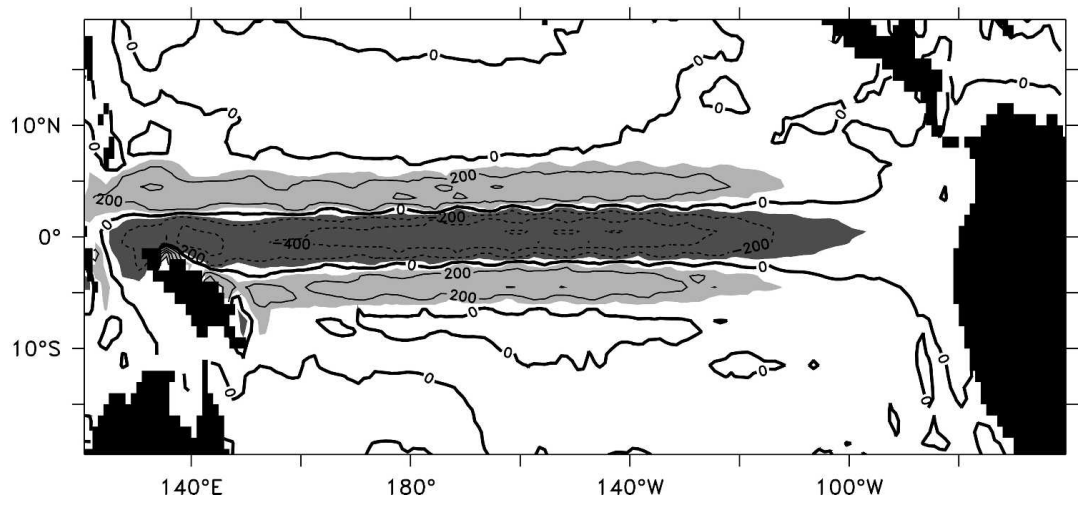

FIG. 9. (a) Mean wind stress (vectors) and magnitude (contours; Pa) in the experiment WSC, (b) changes in wind stress between the experiments WSC and NWSC. Regions where the magnitude of the wind stress is reduced by more than $0.005 \mathrm{~Pa}$ are shaded light gray; regions where the difference exceeds $0.005 \mathrm{~Pa}$ are shaded dark gray. (c) Changes in ocean upwelling $\left(\mathrm{m} \mathrm{yr}^{-1}\right)$ at 50-m depth. Regions where the upwelling difference exceeds $+100 \mathrm{~m}$ $\mathrm{yr}^{-1}$ are shaded light gray; regions where the difference exceeds $-100 \mathrm{~m} \mathrm{yr}^{-1}$ are shaded dark gray.

upwelling. While the structure and magnitude of the surface flux and vertical advection terms compare relatively well with the hindcast simulation of Vialard et al. (2001), the horizontal advection contributions do not appear to be realistic. This is related to the much lower resolution of our model and the poor representation of the surface currents. Comparing the WSC and the
NSWSC simulations, we find the most pronounced changes in the contributions from the heat flux divergences. The changes in the horizontal advection terms act to warm the equatorial Pacific. Directly at the equator, the zonal advection contribution is reduced by roughly $50 \%$. The vertical advection is also reduced but the warming effect appears only in the western Pacific 
a)

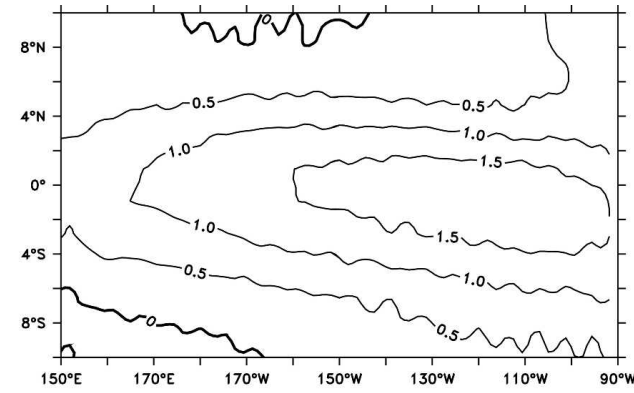

c)

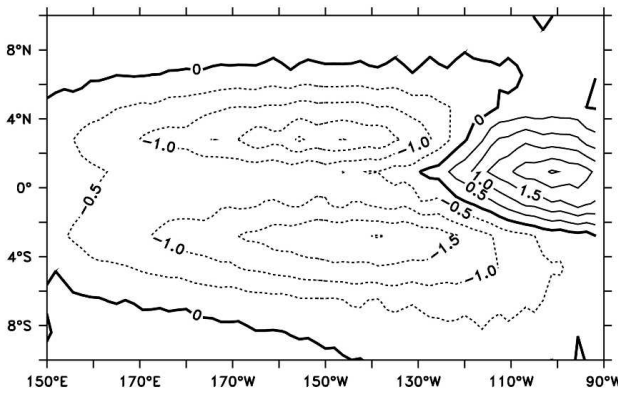

e)

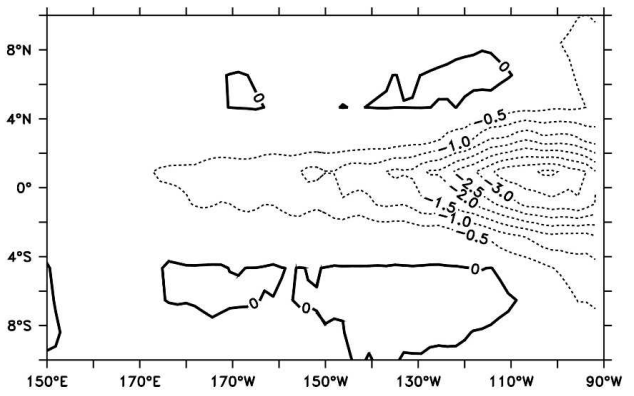

g)

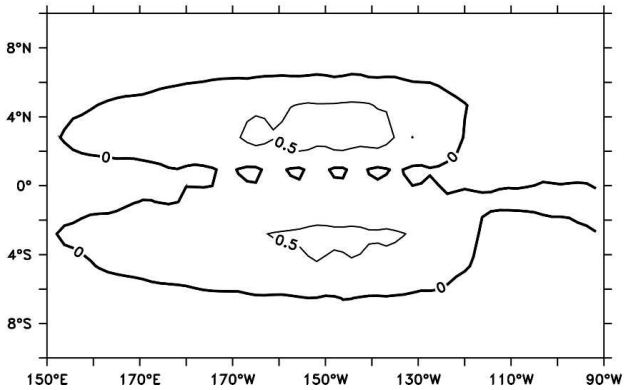

b)

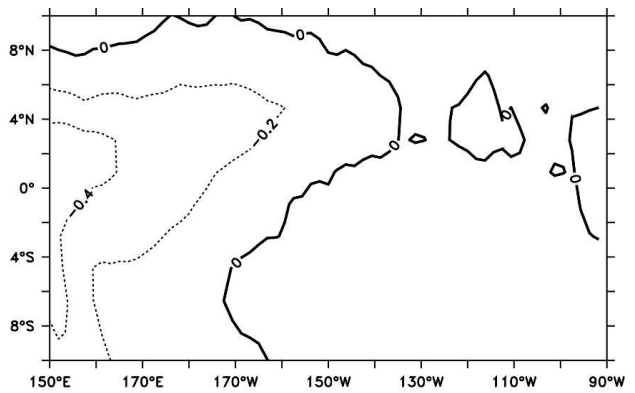

d)

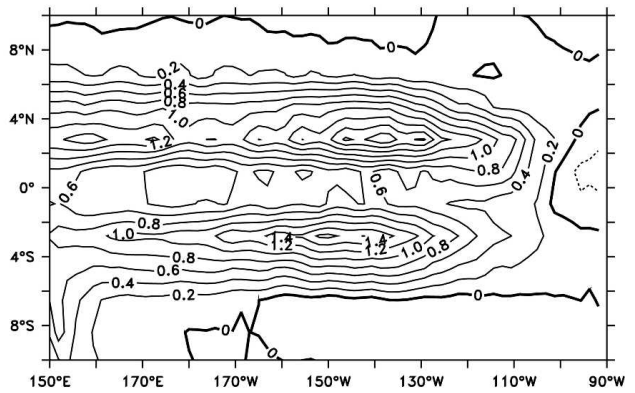

f)

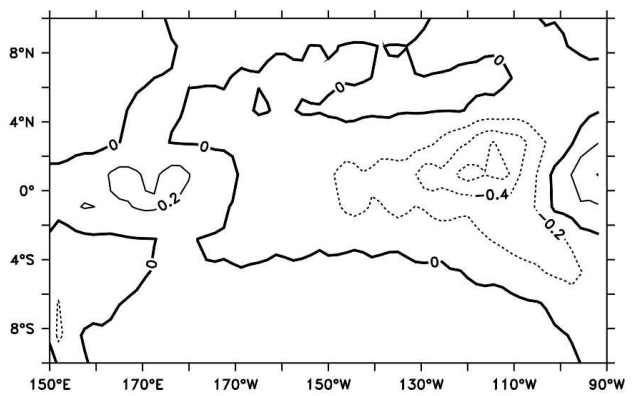

h)

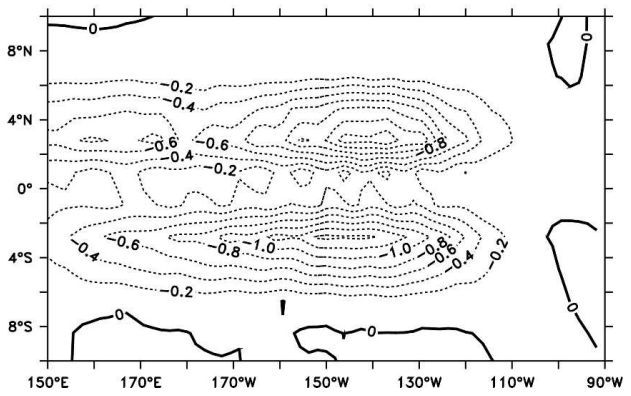

FIG. 10. Tropical Pacific upper-ocean $(50 \mathrm{~m})$ heat budget for (left) the WSC experiment and (right) the difference in the respective heat budget terms between WSC and NWSC. Temperature tendency $\left(\mathrm{K} \mathrm{month}^{-1}\right)$ contributions from (a), (b) the surface heat flux forcing, (c), (d) horizontal advection, (e), (f) vertical advection, and (g), (h) the mixing terms.

owing to changes in the thermocline depth. There is less mixing necessary to balance the advective heat contributions in the regions off the equator (Luo et al. 2005). In the western Pacific, the warmer SSTs have a damping effect on the surface heat fluxes (Figs. 10a,b).

As equatorial upwelling is reduced, the warmer SST in this region is consistent with the atmospheric circulation changes. Thus, the sign of the changes in equa- torial Pacific atmosphere and ocean are easily understood. The magnitude of the changes is, however, strongly modulated by the Bjerknes feedback, which relates changes in zonal wind stress, upwelling, and SST. However, the structure of the mean surface currents is relatively poor, with the simulated SEC having a maximum on the equator, in contrast to the observed minimum (not shown). The simulated Equatorial Un- 
TABLE 1. Statistics for monthly mean anomalies of the Niño-3 index for the years 1953-2002 from the HadISST data, and the last $50 \mathrm{yr}$ of the NWSC and WSC experiments, respectively. Time series are detrended and the seasonal cycle is removed.

\begin{tabular}{lccc}
\hline \hline \multicolumn{1}{c}{ Data } & Std dev & Skewness & Kurtosis-3 \\
\hline HadISST & 0.88 & 0.911 & 1.362 \\
WSC & 1.42 & 0.025 & 0.206 \\
NWSC & 1.79 & 0.034 & 0.280 \\
\hline
\end{tabular}

dercurrent (EUC) is insensitive to the new parameterization. Because of the model's coarse meridional resolution of approximately $1.5^{\circ}$, the model's EUC is $50 \%$ too weak (having a maximum eastward velocity of about $0.4 \mathrm{~m} \mathrm{~s}^{-1}$ ) and meridionally too diffuse. In contrast, the simulated equatorial thermal structure is in good agreement with observations. The mean depth of the 20-degree isotherm along the equator matches the Levitus et al. (1998) climatology well, and the thermocline is only slightly too diffuse. The slope and sharpness of the thermocline are improved over the NWSC simulation, with the largest differences in the western/central Pacific where the thermocline is some $30 \mathrm{~m}$ shallower (not shown) in the WSC case (i.e., the east-west tilt is reduced consistent with the weaker zonal winds).

\section{Simulation of tropical variability}

In this section, the simulated interannual variability of the tropical Pacific is described. The statistics for the Niño-3 monthly mean anomalies (Table 1) indicate that, although the variability is drastically reduced in the WSC compared to the NWSC run, the standard deviation of the simulated SSTs is still roughly $0.5 \mathrm{~K}$ higher than the respective ones from HadISST. Moreover, the higher moments, which indicate the "nonnormality" (Burgers and Stephenson 1999) of ENSO, deviate significantly from the observed data. There is no predominance of El Niño events compared to $\mathrm{La}$ Niña events, and the simulated time series are more or less normally distributed. In the higher moments, we do not see any improvement from the NWSC to the WSC experiment. Why the model underestimates the degree of nonlinearity in ENSO is not clear. Compared to the NWSC run, the spectral peak of the WSC Niño-3 time series is shifted from 3 to $4 \mathrm{yr}$, closer to the 4-6-yr band that characterizes the dominant ENSO period in the observations (Fig. 11).

The model's annual cycle of equatorial SST is characterized by a weak semiannual cycle in the west, and a strong westward-propagating annual cycle in the east (Figs. 12a,b). In the west, the phase and strength match observations well. In the east, the strength is well simu-

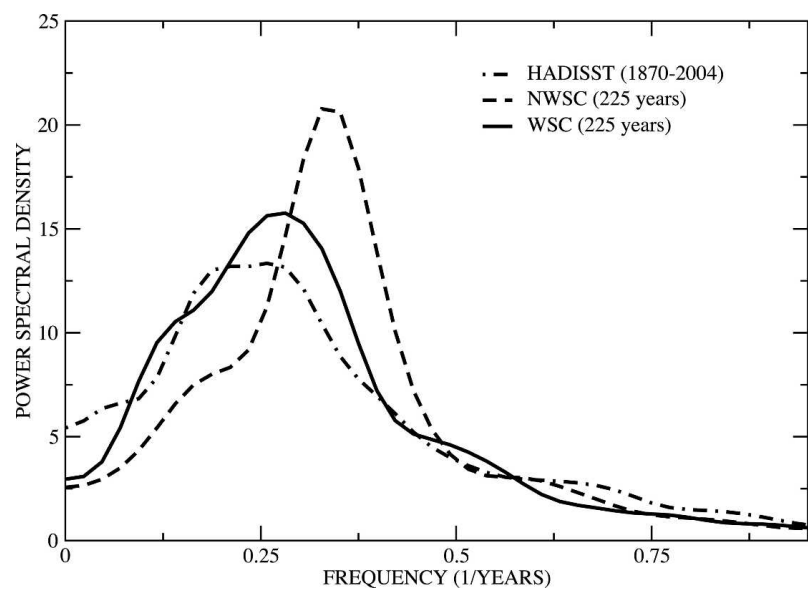

FIG. 11. Power spectra from observed and simulated Niño-3 SST anomalies. Observations are from HadISST for the period 1900 to 1999. Simulated data are from a common 100-yr period. All data were detrended and normalized by their standard deviation.

lated but the positive phase lags observations by $1-2$ months, and the negative phase slightly leads observations. This is an improvement on an earlier version of the model (Keenlyside et al. 2004) and resembles the better-performing models of the ENSIP (Latif et al. 2001). However, this improvement is not due to the shear correction and is more likely related to changes in the mean state, which were much larger between the old and new versions of the model (most likely due to higher resolution in the atmosphere model going from a T42-19 level to a T63-31 level setup). The link between the mean state and the annual cycle has been demonstrated in earlier modeling studies (e.g., $\mathrm{Li}$ and Philander 1996). The simulated variability, however, does not show the pronounced phase locking that was observed. In the WSC experiment, the annual cycle of standard deviations (Fig. 12c) is more flat but shows the observed minimum in April. In the NWSC setup, the minimum is shifted into summer and there is an even more pronounced second minimum in autumn.

The spatial pattern of interannual SST variability is portrayed by the correlation between Niño-3 SST anomalies and global SST anomalies (Fig. 13). In the Pacific, there is good agreement with correlations obtained from observations (HadISST), with realistic meridional structure and strength. The westward extension of variability in the model is, however, too strong. Teleconnected variability is broadly consistent with observations, although discrepancies occur in the equatorial Atlantic and Indian Oceans. Experiments with other AOGCMs indicate that atmospheric resolution is important in shaping tropical Pacific interannual SST variability (Gualdi et al. 2003). A recent intercompari- 
(a)

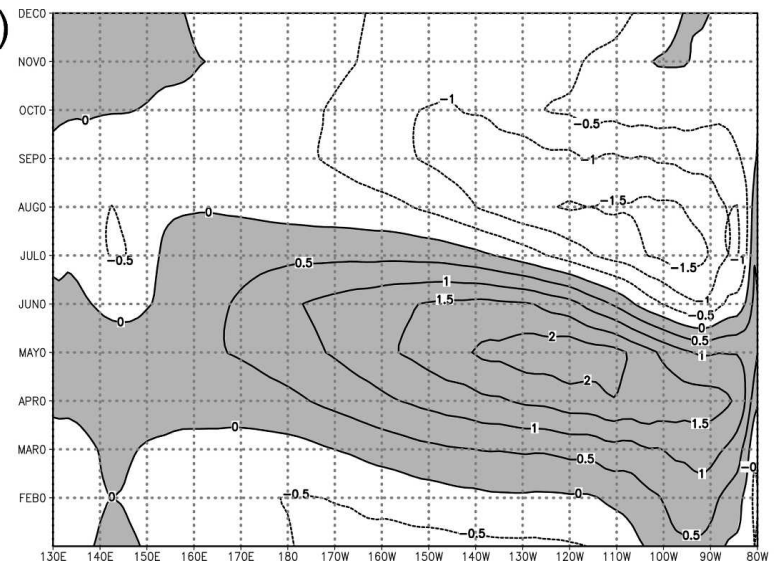

c)

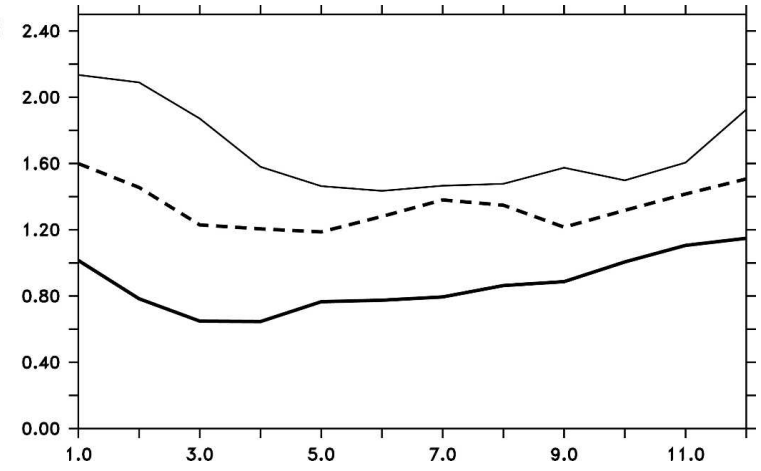

son study by Van Oldenborgh et al. (2005) of 20 IPCC AR4 models has confirmed that the ECHAM5/MPIOM coupled model produces relatively realistic ENSO variability. Given the ocean's coarse meridional resolution in the Tropics, these results support the idea that the atmosphere plays a dominant role in determining important characteristics of interannual SST variability (Guilyardi et al. 2004).

Relative to the NWSC run, there have been several improvements in the simulation of interannual variabil- (b)

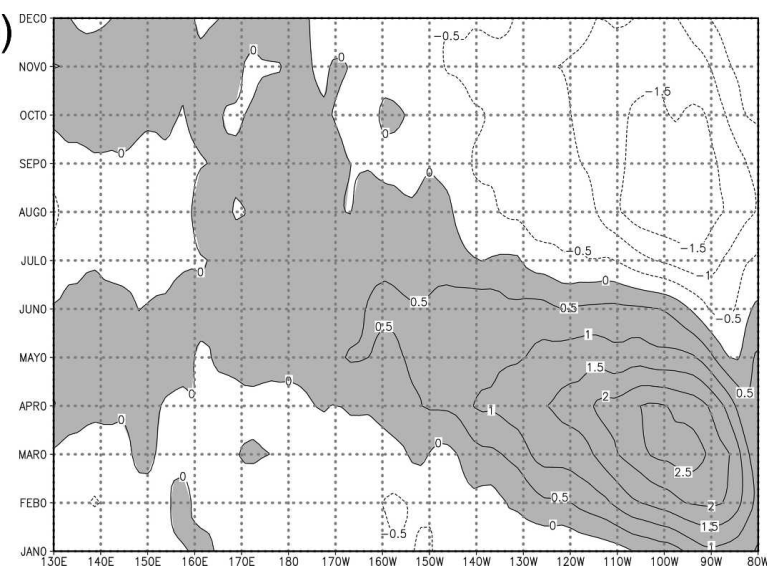

Fig. 12. Annual cycle (K) along the equator $\left(2^{\circ} \mathrm{N}-2^{\circ} \mathrm{S}\right)$; deviations from the annual means for (a) the HadISST data and (b) the last $50 \mathrm{yr}$ of the model simulation. (c) The std dev (K) of Niño-3 SST as a function of the calendar month for the HadISST (19532002) data (thick line), and for the last $50 \mathrm{yr}$ of the WSC (dashed line) and the NWSC experiments (thin solid line).

ity. Equatorial SST variability is dominated by unrealistically strong westward propagation in NWSC (Fig. 14, middle), unlike the WSC simulation (right). The strength of the variability is weakened by about $30 \%$ in the eastern and central Pacific, and the westward extension of the variability into the warm pool is much reduced (Fig. 14). The mechanism of this damping feedback is easily understood: wind anomalies introduce surface current anomalies in the same direction that, in turn, reduce the wind stress anomalies. a)

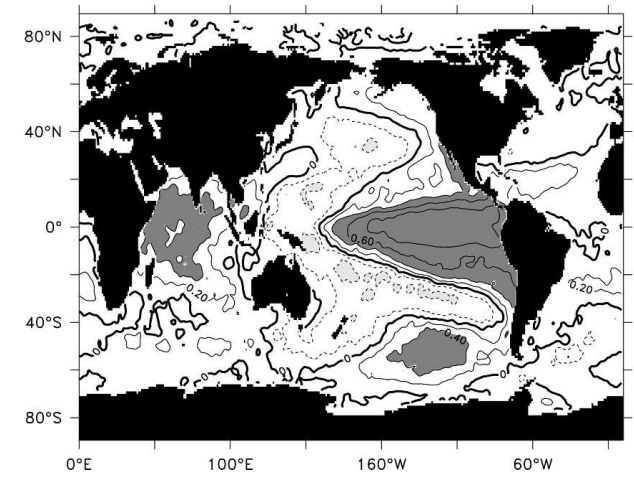

b)

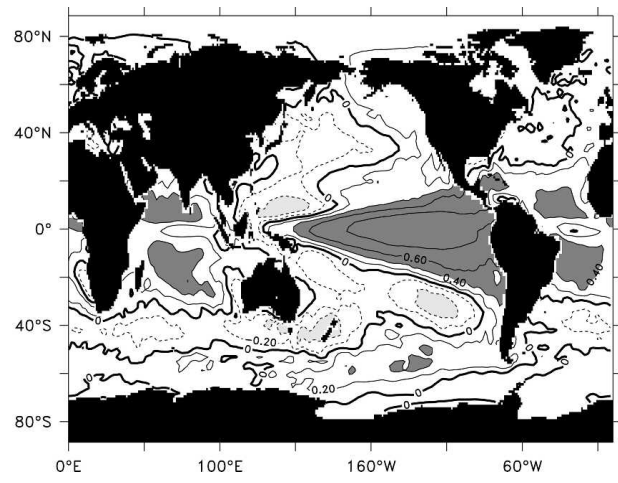

FIG. 13. Correlations between the SST averaged over the Niño-3 region and the global SST for (a) the HadISST and (b) the coupled experiment WSC. Regions where the correlations exceeds +0.4 or -0.4 are shaded dark gray or light gray, respectively. 

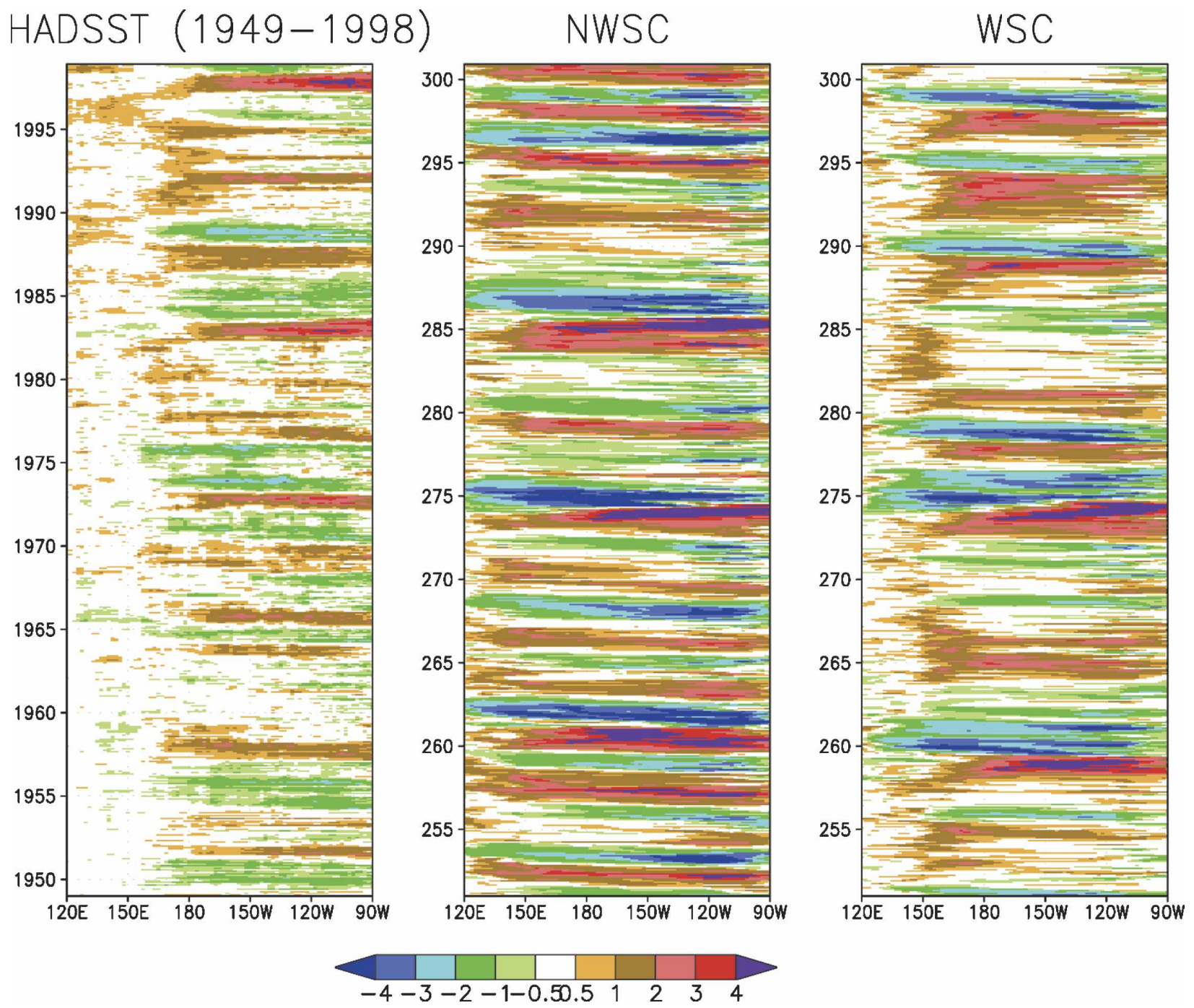

FIG. 14. Evolution of SST anomalies (K) along the equator for (left) the HadISST climatology, (middle) the NWSC, and (right) the WSC experiment.

Equatorial Pacific SST anomalies in the WSC experiment are simulated with an almost standing east-west pattern. Individual events, however, exhibit significant differences, and interdecadal changes in ENSO characteristics are also simulated. In particular, there are strong positive events, which propagate eastward (e.g., model year 273), weak positive events that are confined to the central western Pacific (e.g., around year 270), and periods characterized by weak westward propagation (e.g., model year 255). Negative events also tend to be westward propagating. All these features are reminiscent of observations.

While significant progress has been made in understanding the factors controlling the ENSO period and its damped/undamped nature, the factors that control its amplitude are not well understood. However, it is tacitly understood that changes in the relevant positive/ negative feedbacks will impact ENSO amplitude (as well as period). These changes may be induced through changes in the mean state. For example, experiments with other AOGCMs indicate that ocean background diffusivity, which affects the thermal structure, can strongly affect ENSO amplitude (Meehl el al. 2001).

The feedbacks relevant to the delayed oscillator framework have been estimated in the two simulations using scatterplots and regression analysis among anomalies of SST, $\tau_{\mathrm{x}}$, thermocline depth, and net surface heat flux. The analysis suggests that one reason for the reduced variability is a $O(10 \%)$ reduction of atmospheric (central Pacific zonal wind stress) sensitivity to eastern Pacific SST (Fig. 15). Despite the 30\% reduction in equatorial upwelling in the central Pacific, the 
a)

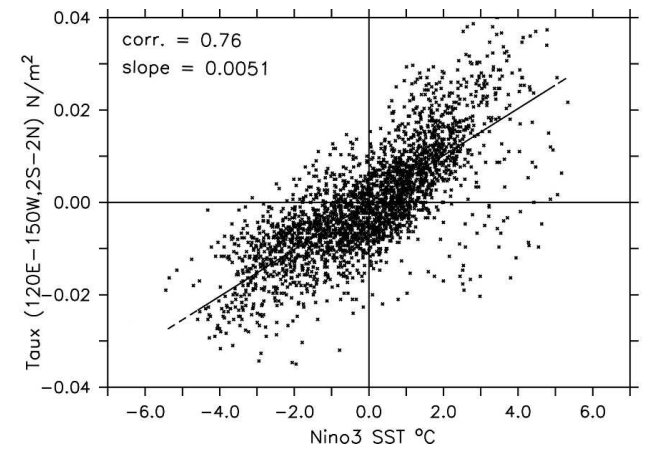

b)

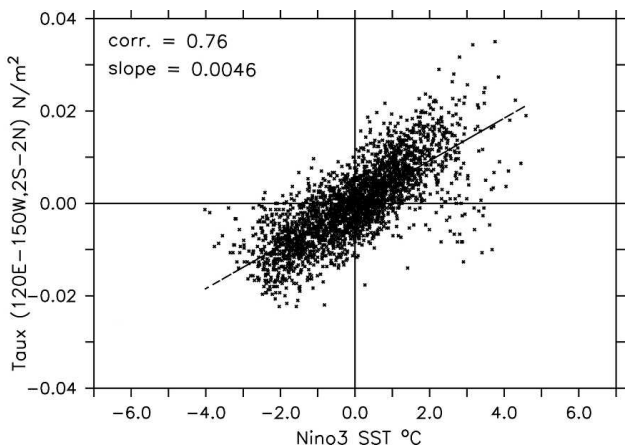

FIG. 15. Scatterplot of the Niño-3 SST anomalies vs the wind stress anomalies over the western equatorial Pacific for (a) the experiment NWSC and (b) the experiment WSC. Anomalies are calculated from model years 78 to 300 after detrending.

eastern Pacific SST-thermocline feedback is not changed, perhaps because of a slightly sharper thermocline with a weaker east-west gradient. The changes in atmospheric sensitivity are certainly partly due to the direct effect of the atmosphere sensing ocean currents, but may well also be due to changes in the mean state.

Changes in the mean state of the ocean appear to contribute to the reduction in variability in other ways as well, given that the wind shear correction only results in a roughly $10 \%$ decrease in atmospheric sensitivity, while there is a $30 \%$ reduction in variability. An analysis of the terms controlling interannual SST variability (Table 2) indicates that the relative role of these terms changes with the introduction of the WSC. With WSC, the vertical advection term strengthens and becomes dominant. This is consistent with the diagnosed changes in SST variability. In particular, the SST propagation characteristics are westward in the NWSC (an SST mode characteristic), and more or less stationary in the WSC run (consistent with a thermocline mode). The reduction in variability may also be interpreted as due to a reduction in the strength of the surface horizontal advective terms, and also to the weakening of the atmospheric sensitivity (see above), both of which are consistent with the impact of the WSC (i.e., reduced wind stress and surface current difference).

TABLE 2. Correlation between the main heat budget tendency terms $(u d T / d t=$ zonal advection, $v d T / d y=$ meridional advection, $w d T / d t=$ vertical advection, and SFHFL $=$ surface heat fluxes $)$ and the SST tendency $(d T / d t)$.

\begin{tabular}{lll}
\hline \hline Experiment & NWSC & WSC \\
\hline$d T / d t$ & 1 & 1 \\
$u d T / d x$ & 0.182 & 0.063 \\
$v d T / d y$ & 0.629 & 0.244 \\
$w d T / d z$ & 0.443 & 0.657 \\
SFHFL & 0.3083 & 0.2097 \\
\hline
\end{tabular}

The improvements in period, propagation characteristics, and westward extension of interannual SST variability in the tropical Pacific are broadly consistent with the theoretical work of Federov and Philander (2001). In particular, there are improvements in the mean state of the model from strong wind/steeper east-west thermocline to a weaker wind/less steep thermocline. A less steep thermocline favors, in the framework of Federov and Philander (2001), a delayed oscillator type mode and a lengthening of the oscillation period.

Luo et al. (2005) have implemented the wind stress correction into the SINTEX-F coupled model consisting of ECHAM4 and the ocean model Océan Parallélisé (OPA). Compared to the model used in the present study, the SINTEX model features higher resolution, both in the atmosphere (T106) and in the equatorial ocean (gradual refinement from $2^{\circ}$ to $0.5^{\circ}$ ). In general, our results confirm the findings of Luo et al. (2005). The equatorial cold bias is significantly reduced in both coupled models. However, there are also differences, for example, the increase in upwelling near the Peruvian coast that does not occur in our study. Luo et al. (2005) describe only a slight decrease of ENSO amplitudes whilst we find a $O(30 \%)$ reduction. These differences are most likely due to differences in the mean state and to the different resolutions. Further improvement of WSC could probably be made by taking into account subgrid-scale dependencies of ocean currents and wind stress. More analysis, both for the individual models but also a cross-model comparison, is, however, needed to better understand the feedback mechanisms.

\section{Summary and conclusions}

We have discussed the main ocean-related results from a 300-yr-long control integration with the MPI-M 
coupled climate model ECHAM5/MPI-OM. The simulation of sea surface temperature and sea ice are shown to be stable and realistic. Global-scale heat and freshwater transports are in broad agreement with observations and the improved compatibility of the ocean and atmospheric heat budgets allows for the simulation of a stable climate without flux adjustment. Although there are temperature and salinity drifts in the intermediate and deep ocean, the changes in water mass properties are not large enough to seriously influence the largescale circulation. The North Atlantic overturning circulation and the associated heat and freshwater transports are stable. There is, however, insufficient Antarctic Bottom Water formation that leads to a significant reduction of the AABW overturning cell. Here, a better simulation of bottom water formation on the Antarctic shelves is needed.

Ocean velocities are taken into account in the calculation of the wind stresses following Luo et al. (2005), rather than assuming an immobile surface as a lower boundary condition. The WSC modification has beneficial effects, mainly in the tropical Pacific. Not only is the cold bias reduced by more than $1 \mathrm{~K}$, there are also improvements in the simulation of tropical variability. The strength of the variability is reduced as well as the extension of SST variability into the western Pacific. The ENSO period is more realistically simulated, with a dominant period of $4 \mathrm{yr}$. Despite these improvements, the shear correction has no beneficial impact on the warm bias in the eastern ocean basins, the simulation of the equatorial annual cycle of SST, the skewness of SST anomalies, or the seasonality of the variability.

The WSC is a good example of improving model simulations not by tuning individual components, but by improving the coupling physics. Another such example is the inclusion of the effect of interactive phytoplankton on the short-wave penetration depth studied by Wetzel et al. (2006) using another model version coupled to the Hamburg Ocean Carbon Cycle model (HAMOCC5). Wetzel et al. (2006) find a considerable warming of the entire equatorial Pacific, a reduced ENSO amplitude, and an amplification in the seasonal cycle in the case of interactive biology.

Acknowledgments. The funding for this study was provided by the German Ministry for Education and Research (BMBF) research programs OCEAN CLIVAR and DEKLIM. The comments and suggestions of two anonymous reviewers were helpful in improving the manuscript. The model experiments were carried out on the supercomputing system of the German Climate Computation Center (DKRZ) Hamburg.

\section{REFERENCES}

Aagaard, K., and E. C. Carmack, 1989: The role of sea ice and other fresh water in the Arctic circulation. J. Geophys. Res., 94, 14 485-14 498.

Arakawa, A., and V. R. Lamb, 1977: Computational design of the basic dynamical processes of the UCLA general circulation model. Methods Comput. Phys., 17, 173-265.

Barthelet, P., L. Terray, and S. Valcke, 1998: Transient $\mathrm{CO}_{2}$ experiment using the ARPEGE/OPAICE non flux corrected coupled model. Geophys. Res. Lett., 25, 2277-2280.

Burgers, G., and D. B. Stephenson, 1999: The "normality" of El Niño. Geophys. Res. Lett., 26, 1027-1030.

Colony, R., and A. S. Thorndike, 1984: An estimate of the mean field of Arctic Sea Ice motion. J. Geophys. Res., 89, $10623-$ 10629 .

Dai, A., 2006: Precipitation characteristics in eighteen coupled climate models. J. Climate, in press.

Da Silva, A. M., C. Young, and S. Levitus, 1994: Algorithms and Procedures. Vol. 1, Atlas of Surface Marine Data 1994, NOAA Atlas NESDIS 6, $83 \mathrm{pp}$.

Emery, W. J., C. W. Fowler, and J. A. Maslanik, 1997: Satellitederived maps of Arctic and Antarctic sea ice motion: 1988 to 1994. Geophys. Res. Lett., 24, 897-900.

Federov, A. V., and S. G. Philander, 2001: A stability analysis of tropical ocean-atmosphere interactions: Bridging measurements and theory for El Niño. J. Climate, 14, 3086-3101.

Ganachaud, A., and C. Wunsch, 2000: Improved estimates of global ocean circulation, heat transport and mixing from hydrographic data. Nature, 408, 453-456.

— and - 2003: Large-scale ocean heat and freshwater transports during the World Ocean Circulation Experiment. $J$. Climate, 16, 696-705.

Gent, P. R., J. Willebrand, T. McDougall, and J. C. McWilliams, 1995: Parameterizing eddy-induced tracer transports in ocean circulation models. J. Phys. Oceanogr., 25, 463-474.

_ , F. O. Bryan, G. Donabasoglu, S. C. Doney, W. R. Holland, W. G. Large, and J. C. McWilliams, 1998: The NCAR Climate System Model global ocean component. J. Climate, 11, 1287-1306.

—, W. G. Large, and F. O. Bryan, 2001: What sets the mean transport through Drake Passage? J. Geophys. Res., 106 (C2), 2693-2712.

Gordon, A. L., 1978: Deep Antarctic convection west of Maud Rise. J. Phys. Oceanogr., 8, 600-612.

Gordon, C., C. Cooper, C. A. Senior, H. Banks, J. M. Gregory, T. C. Johns, J. F. B. Mitchell, and R. A. Wood, 2000: The simulation of SST, sea ice extents and ocean heat transports in a version of the Hadley Centre coupled model without flux adjustment. Climate Dyn., 16, 147-168.

Griffies, S. M., 1998: The Gent-McWilliams skew flux. J. Phys. Oceanogr., 28, 831-841.

Gualdi, S., A. Navarra, E. Guilyardi, and P. Delecluse, 2003: Assessment of the tropical Indo-Pacific climate in the SINTEX CGCM. Ann. Geophys., 46, 1-26.

Guilyardi, E., and Coauthors, 2004: Representing El Niño in coupled ocean-atmosphere GCMs: The dominat role of the atmospheric component. J. Climate, 17, 4623-4629.

Hagemann, S., and L. Dümenil, 1998: A parameterization of the lateral waterflow for the global scale. Climate Dyn., 14, 17-31. , and L. Dümenil-Gates, 2003: An improved sub grid runoff parameterization scheme for climate models. Climate Dyn., 21, 349-359. 
Halpern, D., 1988: Moored surface wind observations at four sites along the Pacific equator between $140^{\circ}$ and $95^{\circ} \mathrm{W}$. J. Climate, 1, 1251-1260.

Hibler, W. D., III, 1979: A dynamic thermodynamic sea ice model. J. Phys. Oceanogr., 9, 815-846.

Houghton, J. T., Y. Ding, D. J. Griggs, M. Noguer, P. J. van der Linden, X. Dai, K. Maskell, and C. A. Johnson, Eds., 2001: Climate Change 2001: The Scientific Basis. Cambridge University Press, $881 \mathrm{pp}$.

Huang, B., and Z. Liu, 2002: An OGCM simulation of seasonal and interannual variabilities in the surface-layer Pacific of the equatorial band. Adv. Atmos. Sci., 19, 219-235.

Johns, W. E., T. N. Lee, R. J. Zantopp, and E. Fillenbaum, 1997: Updated transatlantic heat flux at $26.5 \mathrm{~N}$. International WOCE Newsletter, No. 27, WOCE International Project Office, Southampton, United Kingdom, 15-22.

Josey, S. A., E. C. Kent, D. Oakley, and P. K. Taylor, 1996: A new global air-sea heat and momentum flux climatology. International WOCE Newsletter, No. 24, WOCE International Project Office, Southampton, United Kingdom, 3-5.

Keenlyside, N., M. Latif, M. Botzet, J. Jungclaus, and U. Schulzweida, 2004: A coupled method for initialising ENSO forecasts using SST data. Tellus, 57A, 340-356.

Kiehl, J. T., and P. R. Gent, 2004: The Community Climate System Model, version 2. J. Climate, 17, 3666-3682.

Kwok, R., G. F. Cunningham, and S. S. Pang, 2004: Fram Strait sea ice outflow. J. Geophys. Res., 109, C01009, doi:10.1029/ 2003JC001785.

Large, W. G., and S. Pond, 1981: Open ocean momentum flux measurements in moderate to strong winds. J. Phys. Oceanogr., 11, 324-326.

, G. Danansoglu, J. C. McWilliams, P. Gent, and F. O. Bryan, 2001: Equatorial circulation of a global ocean climate model with anisotropic horizontal viscosity. J. Phys. Oceanogr., 31, $518-536$.

Larsen, J. C., 1992: Transport and heat flux of the Florida Current at $27^{\circ} \mathrm{N}$ derived from cross-stream voltages and profiling data. Philos. Trans. Roy. Soc. London, A338, 169-236.

Latif, M., E. Roeckner, U. Mikolajewicz, and R. Voss, 2000: Tropical stabilization of the thermohaline circulation in a greenhouse warming simulation. J. Climate, 13, 1809-1813.

— - and Coauthors, 2001: ENSIP: The El Niño simulation intercomparison project. Climate Dyn., 18, 255-276.

Levitus, S., and Coauthors, 1998: Introduction. Vol. 1, World Ocean Database 1998, NOAA Atlas NESDIS 18, 346 pp.

Li, T. M., and S. G. H. Philander, 1996: On the annual cycle of the eastern equatorial Pacific. J. Climate, 9, 2986-2998.

Li, J. L., X. H. Zhang, Y. Q. Yu, and F. S. Dai, 2004: Primary reasoning behind the double ITCZ phenomenon in a coupled ocean-atmosphere general circulation model. Adv. Atmos. Sci., 21, 857-867.

Luo, J.-J., S. Masson, E. Roeckner, G. Madec, and T. Yamagata, 2005: Reducing climatology bias in an ocean-atmosphere CGCM with improved coupling physics. J. Climate, 18, 23442360.

Macdonald, A. M., 1998: The global ocean circulation: A hydrographic estimate and regional analysis. Progress in Oceanography, Vol. 41, Pergamon, 281-382.

— , and C. Wunsch, 1996: Oceanic estimates of global ocean heat transport. International WOCE Newsletter, No. 24, WOCE International Project Office, Southampton, United Kingdom, 5-6.

Marsland, S. J., H. Haak, J. H. Jungclaus, M. Latif, and F. Röske,
2003: The Max- Planck-Institute global ocean/sea ice model with orthogonal curvilinear coordinates. Ocean Modell., 5, 91-127.

—, N. L. Bindoff, G. D. Williams, and W. F. Budd, 2004: Modeling water mass formation in the Mertz Glacier Polynya and Adelie Depression, East Antarctic. J. Geophys. Res., 109, C11003, doi:10.1029/2004JC002441.

Mechoso, C. R., and Coauthors, 1995: The seasonal cycle over the tropical Pacific in coupled ocean-atmosphere general circulation models. Mon. Wea. Rev., 123, 2825-2838.

Meehl, G., P. R. Gent, J. M. Arblaster, B. L. Otto-Bliesner, E. C. Brady, and A. Craig, 2001: Factors that affect the amplitude of El Niño in global coupled climate models. Climate Dyn., 17, 515-526.

National Geophysical Data Center, 1988: Digital relief of the surface of the Earth. Data Announcement 88-MGG-02, NOAA, Boulder, CO.

Nowlin, W. D. J., and J. M. Klinck, 1986: The physics of the Antarctic Circumpolar Current. Rev. Geophys., 24, 469-491.

Orsi, A. H., G. C. Johnson, and J. L. Bullister, 1999: Circulation, mixing, and production of Antarctic Bottom Water. Progress in Oceanography, Vol. 43, Pergamon, 55-109.

Pacanowski, R. C., 1987: Effect of equatorial currents on surface stress. J. Phys. Oceanogr., 17, 833-838.

_ and S. G. H. Philander, 1981: Parameterization of vertical mixing in numerical models of tropical oceans. J. Phys. Oceanogr., 11, 1443-1451.

Pickart, R. S., D. T. Torres, and R. A. Clarke, 2002: Hydrography of the Labrador Sea during active convection. J. Phys. Oceanogr., 32, 428-457.

Polyakov, I. V., and M. A. Johnson, 2000: Arctic decadal and interdecadal variability. Geophys. Res. Lett., 27, 4097-4100.

Proshutinsky, A., R. H. Bourke, and F. A. McLaughlin, 2002: The role of the Beaufort Gyre in Arctic climate variability: Seasonal to decadal climate scales. Geophys. Res. Lett., 29, 2100, doi:101029/2002GL015847.

Rayner, N. A., D. E. Parker, E. B. Holton, C. K. Folland, L. V. Alexander, D. P. Rowell, E. C. Kent, and A. Kaplan, 2003: Global analyses of sea surface temperature, sea ice, and night marine air temperature since the late nineteenth century. $J$. Geophys. Res., 108, 4407, doi:10.1029/2002JD002670.

Redi, M. H., 1982: Oceanic isopycanal mixing by coordinate rotation. J. Phys. Oceanogr., 12, 1154-1158.

Rintoul, S. R., and C. Wunsch, 1991: Mass, heat, oxygen and nutrient fluxes and budgets in the North Atlantic Ocean. DeepSea Res., 38 (Suppl. 1), S355-S377.

_ and S. Sokolov, 2001: Baroclinic transport variability of the Antarctic Circumpolar Current south of Australia (WOCE repeat section SR3). J. Geophys. Res., 106 (C2), 2815-2832.

Roberts, M. J., and Coauthors, 2004: Impact of an eddypermitting ocean resolution on control and climate change simulations with a global coupled GCM. J. Climate, 17, 3-20.

Roeckner, E., and Coauthors, 2003: The atmospheric general circulation model ECHAM5, Part I: Model description. MaxPlanck-Institut für Meteorologie, Rep. 349, 127 pp.

Ross, C. K., 1984: Temperature-salinity characteristics of the "overflow" water in Denmark Strait during "Overflow '73." Rapp. P. V. Reun. Cons. Int. Explor. Mer., 185, 111-119.

Saunders, P., 1990: Cold outflow from the Faroe Bank Channel. J. Phys. Oceanogr., 20, 29-43.

Sloyan, B., and S. Rintoul, 2001: The Southern Ocean limb of the global deep overturning circulation. J. Phys. Oceanogr., 31, 143-173. 
Steele, M., R. Morley, and W. Ermold, 2001: PHC: A global ocean hydrography with a high-quality Arctic Ocean. J. Climate, 14, 2079-2087.

Talley, L. D., J. L. Reid, and P. E. Robbins, 2003: Data-based meridional overturning streamfunctions for the global ocean. J. Climate, 16, 3213-3226.

Trenberth, K. E., and A. Solomon, 1994: The global heat balance: Heat transports in the atmosphere and ocean. Climate Dyn., 10, 107-134.

Valcke, S., A. Caubel, D. Declat, and L. Terray, 2003: OASIS Ocean Atmosphere Sea Ice Soil users's guide. CERFACS Tech. Rep. TR/CMGC/03/69, Toulouse, France, 85 pp.

van Oldenborgh, G. J., S. Y. Philips, and M. Collins, 2005: El Niño in a changing climate: A multi model study. Ocean Sci., 1, $81-95$.

Vialard, J., C. Menkes, J.-P. Boulanger, P. Delecluse, E. Guilyardi, M. J. McPhaden, and G. Madec, 2001: A model study of oceanic mechanisms affecting equatorial Pacific sea surface temperature during the 1997-98 El Niño. J. Phys. Oceanogr., 31, 1649-1675.

Vinje, T., 2001: Fram Strait ice fluxes and atmospheric circulation: 1950-2000. J. Climate, 14, 3508-3517.

Washington, W. M., and Coauthors, 2000: Parallel climate model (PCM) control and transient simulations. Climate Dyn., 16, 755-774.

Weisberg, R. H., 1984: Seasonal adjustments in the equatorial Atlantic during 1983 as seen by surface moorings. Geophys. Res. Lett., 11, 733-735.
- and L. Qiao, 2000: Equatorial upwelling in the central Pacific estimated from moored velocity profilers. J. Phys. Oceanogr., 30, 105-124.

Wetzel, P., E. Maier-Reimer, M. Botzet, J. Jungclaus, N. Keenlyside, and M. Latif, 2006: Effects of ocean biology on the penetrative radiation in a coupled climate model. J. Climate, 19, 3973-3987.

Wijffels, S., 2001: Ocean transport of freshwater. Ocean Circulation and Climate, G. Siedler et al., Eds., Academic Press, 475-488.

_ N. Bray, S. Hautala, G. Meyers, and W. M. L. Morawitz, 1996: The WOCE Indonesian throughflow repeat sections: I10 and IR6. International WOCE Newsletter, No. 24, WOCE International Project Office, Southampton, United Kingdom, $25-28$.

Willis, J. K., D. Roemmich, and B. Cornuelle, 2004: Interannual variability in upper ocean heat content, temperature, and thermosteric expansion on global scales. J. Geophys. Res., 109, C12036, doi:10.1029/2003JC002260.

Wolff, J. O., E. Maier-Reimer, and S. Legutke, 1997: The Hamburg Ocean Primitive Equation Model HOPE. Tech. Rep. 13, German Climate Computer Center (DKRZ), Hamburg, Germany, $98 \mathrm{pp}$.

Xie, P., and P. A. Arkin, 1997: Global precipitation: A 17-year monthly analysis based on gauge observations, satellite estimates, and numerical model outputs. Bull. Amer. Meteor. Soc., 78, 2539-2558. 